\title{
INDUÇÃO EXPERIMENTAL DE ANACORESE NO PERIÁPICE DE DENTES APÓS OBTURAÇÃO DOS CANAIS. ESTUDO EM CÃES EM REGIÃO GEOGRÁFICA ENDÊMICA PARA LEISHMANIOSE
}

\section{ELOI DEZAN JUNIOR}

Tese apresentada à Faculdade de Odontologia de Bauru, da Universidade de São Paulo, como parte dos requisitos para obtenção do título de Doutor em Odontologia, área de Endodontia.

(edição revisada)

\section{BAURU}




\section{INDUÇÃO EXPERIMENTAL DE ANACORESE NO PERIÁPICE DE DENTES APÓS OBTURAÇÃO DOS CANAIS. \\ ESTUDO EM CÃES EM REGIÃO GEOGRÁFICA ENDÊMICA \\ PARA LEISHMANIOSE}

\section{ELOI DEZAN JUNIOR}

Tese apresentada à Faculdade de Odontologia de Bauru, da Universidade de São Paulo, como parte dos requisitos para obtenção do título de Doutor em Odontologia, área de Endodontia.

Orientador: Prof. Dr. Alberto Consolaro

(edição revisada)

BAURU

2001 
Dezan Junior, Eloi

$D 533 i$

Indução experimental de anacorese no periápice de dentes após obturação dos canais: estudo em cães em região geográfica endêmica para leishmaniose / Eloi Dezan Junior. - Bauru, 2001.

78 p. : il.; $30 \mathrm{~cm}$.

Tese. (Doutorado) - Faculdade de Odontologia de Bauru. Universidade de São Paulo.

Orientador: Prof. Dr. Alberto Consolaro

Autorizo, exclusivamente para fins acadêmicos e científicos, a reprodução total ou parcial desta tese, por processos fotocopiadores e outros meios eletrônicos.

Data: $\quad 3$ de outubro de 2001

Projeto de pesquisa aprovado pela Comissão de Ética na Experimentação Animal (CEEA-FOA), em reunião de 10 de agosto de 1999. 


\section{ELOI DEZAN JUNIOR}

22 de abril de 1969

Birigüi SP

$1987-1990$

$1991-1994$

1994

1994-2001

$1997-2001$
Nascimento

Curso de Odontologia - Faculdade de Odontologia do câmpus de Araçatuba UNESP

Curso de Pós Graduação em Odontologia. Mestrado em Endodontia pela Faculdade de Odontologia da Universidade Federal do Rio de Janeiro - UFRJ

ESPECIALISTA EM ENDODONTIA, título registrado no CFO sob o no SR-E 1047/94, no livro ED 8 fls. $72 v$ em 19 de outubro de 1.994, e no CRO-SP sob processo no $247 / 94$, inscrito no Livro 20 fls. $130 \mathrm{v}$ em 18 de novembro de 1.994 .

Professor Assistente da Disciplina de Endodontia da Faculdade de Odontologia do câmpus de Araçatuba UNESP

Curso de Pós Graduação em Odontologia nível Doutorado área Endodontia. Faculdade de Odontologia de Bauru da Universidade de São Paulo - USP 


\section{DEDICATÓRIA}

Deus, o grande arquiteto do Universo, meu eterno companheiro de todos os momentos, vencemos mais uma batalha amparado por nossos companheiros espirituais.

Vanessa, Matheus e bebê, minha família, sem o amor, a compreensão e a paciência de vocês, não teria conseguido superar os momentos mais difíceis, obrigado.

Aos meus pais, Eloi e Ines, grande incentivadores, nunca medindo esforços para me formar. Obrigado por mais uma jornada.

a vocês devo este trabalho 


\section{AGRADECIMENTOS}

Nenhum só homem é capaz de fazer algo sozinho. Neste momento agradeço a todas as pessoas e instituições que me auxiliaram na execução deste trabalho:

- PESSOAS:

Alceu Berbert

Alexandrina Maria Pereira

Alunos de Graduação da Faculdade de Odontologia de Bauru

Alunos de Graduação e Especialização da Faculdade de Odontologia de Araçatuba

Bernadete Aparecida Alves Camargo

Bibliotecários e funcionários da biblioteca da Faculdade de Odontologia de Araçatuba

Bibliotecários e funcionários da biblioteca da Faculdade de Odontologia de Bauru

Cleide Vital Martins

Colegas contemporâneos de Pós Graduação 1997-2001

Colegas de Doutorado da Endodontia

Colegas de Doutorado da Patologia: Cássio, Francisco, Liliana, Nilce, Simone, Mírian

Colegas do Mestrado da Endodontia e da Patologia

Cristhian Giampietro Brandão

Denise Tostes Oliveira

Edimauro de Andrade

Família Braga (Birigüi - SP)

Família Dezan (Birigüi - SP)

Família Marchini (Bauru - SP)

Fátima Aparecida Silveira

Funcionários do setor de Biotério da FOA - UNESP

Guilherme Garcetti Ribeiro

Hermelinda de Jesus Brefore

Ilan Sampaio do Vale 
Ivaldo Gomes de Moraes, grande mestre

José Arlindo Otoboni Filho

Luíz Antônio de Assis Taveira

Marco Antônio Húngaro Duarte

Maria Cecília Rui Luvizoto

Maria Cristina Carrara Felipe

Maria e Nilda Trecco, minhas tias

Mauro Juvenal Nery

Mauro Machado Vieira

Neide Leandro

Nelci Vieira Ferreira

Neuza Angélica dos Santos

Norberti Bernardineli

Patrícia Fernanda Vital Lopes (legionária)

Professores dos cursos de pós graduação da FOB - USP

Roberto Brandão Garcia

Suely Regina Bettio

Sylvia Helena Guimarães

Valdir de Souza

Valdir João Afonso

Valéria de Queiroz Marcondes Zagatto

Vanessa Soares Lara

Wilson Galhego Garcia 
- AGRADECIMENTOS INSTITUCIONAIS:

USP - Faculdade de Odontologia de Bauru

UNESP - Faculdade de Odontologia de Araçatuba

Biblioteca da Faculdade de Odontologia de Bauru

Biblioteca da Faculdade de Odontologia de Araçatuba

CAPES - programa de bolsas PICD

Disciplina de Endodontia da Faculdade de Odontologia de Bauru

Disciplina de Endodontia da Faculdade de Odontologia de Araçatuba

Disciplina de Patologia da Faculdade de Odontologia de Bauru

Disciplina de Microbiologia da Faculdade de Odontologia de Araçatuba

Departamento de Odontologia Restauradora da Faculdade de Odontologia de Araçatuba

Secretaria de Pós Graduação da Faculdade de Odontologia de Bauru 


\section{AGRADECIMENTOS ESPECIAIS}

Prof. Dr. Clóvis Monteiro Bramante - Coordenador do curso de pós graduação em Endodontia, Vice-diretor da Faculdade de Odontologia de Bauru, pela oportunidade concedida de participar deste curso

Prof. Dr. Alberto Consolaro, meu orientador, pela paciência e compreensão que regeu meu aprendizado

Professores da Disciplina de Endodontia da FOB, pela amizade que se concretizou e trocas de informações

Professores da Disciplina de Endodontia da FOAraçatuba, pela possibilidade da realização deste curso

Prof. Dr. Élerson Gaetti Jardim Jr, companheiro de longa jornada, pela coautoria do trabalho

Prof. Dr. Roberto Holland, eterno mestre, meu reconhecimento especial

Prof. Dr. Pedro Felício Estrada Bernabé, grande companheiro e incentivador do meu progresso

Dimitrios TZIAFAS (Grécia),

Göran SUNQVIST (Suécia)

Gilberto Jirair DEBELIAN (Noruega)

P. N. Ramachandran NAIR (Suíça)

pela presteza demonstrada na resposta de correspondências 


\section{SUMÁRIO}

RESUMO

1 INTRODUÇÃO 1

2 REVISÃO DA LITERATURA 6

3 PROPOSIÇÃO 16

4 MATERIAL E MÉTODOS 18

$\begin{array}{lll}4.1 & \text { Trabalho experimental } & 19\end{array}$

$\begin{array}{lll}4.2 & \text { Microrganismo } & 21\end{array}$

$\begin{array}{ll}\text { 4.2.1 Obtenção do microrganismo } & 21\end{array}$

4.2.2 Inoculação nos animais experimentais 23

$\begin{array}{lll}4.3 & \text { Remoção das peças teciduais } & 23\end{array}$

4.4 Recuperação do microrganismo inoculado 24

4.5 Confirmação da identidade do microrganismo recuperado 24

4.6 Preparo para análise microscópica 25

4.6.1 Fixação 25

4.6.2 Desmineralização 25

4.6.3 Inclusão e microtomia 25

4.6.4 Coloração 25

$\begin{array}{lll}4.7 & \text { Análise microscópica } 26\end{array}$

5 RESULTADOS 28

5.1 Análise microbiológica da recuperação do microrganismo isolado $\quad 29$

5.2 Análise microscópica 31

5.2.1 Observações relativas à morfologia 31

5.2.2 Observações relativas à presença e localização das bactérias 33

5.3 Observações relativas à presença e localização de Leishmania sp. 
6 DISCUSSÃO 43

6.1 Da concepção 44

$\begin{array}{lll}6.2 & \text { Da metodologia } & 47\end{array}$

6.2.1 Do tratamento endodôntico 47

6.2.2 Emprego de microrganismo com marcador 49

6.2.3 Processamento laboratorial das peças 50

6.3 Dos resultados 51

6.3.1 Implantação de microrganismo exógeno 51

6.3.2 Microrganismos diferentes que apareceram nos espécimes de 30 dias após bacteremia 53

6.3.3 Os porquês de não aparecer os microrganismos 53

6.3.4 Dos achados microscópicos 55

$7 \quad$ CONCLUSÕES $\quad 62$

$\begin{array}{ll}\text { ANEXOS } & 64\end{array}$

$\begin{array}{ll}\text { REFERÊNCIAS BIBLIOGRÁFICAS } & 68\end{array}$

$\begin{array}{ll}\text { ABSTRACT } & 77\end{array}$ 


\section{RESUMO}

Anacorese é o fenômeno pelo qual microrganismos circulantes, corantes, pigmentos, substâncias metálicas, proteínas estranhas e outros materiais são fixados em áreas circunscritas de inflamação. Objetivando verificar anacorese em região periapical, 104 raízes de dentes de quatro cães foram tratadas endodonticamente com cimento de óxido de zinco e eugenol, metade delas obturadas no limite canatdentina-cemento e as demais sobreobturadas. Após 120 dias do tratamento endodôntico, bacteremia experimental foi induzida pela inoculação endovenosa de $4 \mathrm{ml}$ de uma suspensão de $5.10^{6} \mathrm{UFC} / \mathrm{ml}$ de Streptococcus pyogenes com diferentes marcadores de resistência a antimicrobianos. O sacrifício dos animais ocorreu 48 horas e 30 dias após a inoculação bacteriana. A análise microbiológica dos tecidos periapicais, evidenciou a presença do microrganismo inoculado 48 horas após a bacteremia, mas não após 30 dias. Cortes microscópicos evidenciaram bactérias, morfologicamente semelhantes às inoculadas, em $46,88 \%$ dos casos para o período de 48 horas e outros microrganismos em $28,12 \%$ após 30 dias, sendo que algumas sugerem morfologicamente as inoculadas, distribuídas pelo canal cementário, delta apical, periodonto apical e lateral em ambos os períodos. Em dois animais, detectou-se também a presença da Leishmania sp. $\mathrm{O}$ periápice de dentes tratados endodonticamente mostrourse propício à anacorese, independentemente do nível de obturação. Esses microrganismos podem persistir ou colaborar com a colonização da região por outras espécies mais sensíveis. O modelo experimental mostrourse adequado para o estudo de anacorese. 


\section{INTRODUÇÃO}


As bactérias são os principais agentes etiológicos das pulpopatias e periapicopatias. A cárie dentária constitui-se na principal fonte de contaminação do tecido pulpar e do periodonto apical. Não raramente, a contaminação pulpar leva à necrose; o traumatismo dentário representa a segunda causa de necrose pulpar.

A via hematogênica deve também ser ressaltada; as bactérias podem atingir o tecido pulpar pela corrente sangüínea durante uma bacteremia, a qual designa a presença transitória de bactérias no sangue sem ocorrência de multiplicação.

Alguns fatores podem ocasionar bacteremia: escovação dentária, alimentação, uso do fio dental, barbear, depilação, banho e lesões cutâneas.

Durante o dia, por vários momentos, estamos sujeitos à ocorrência de bacteremias; os microrganismos são eliminados da circulação comumente após 10 a 30 minutos $^{30}$.

A presença de bactéria no sangue não apresenta maiores transtornos ao organismo quando este se mostra apto para sua eliminação em alguns órgãos. Apesar de comum, a entrada desses microrganismos não é muito fácil, pois se têm significativos mecanismos de defesa.

As primeiras formas de defesa do organismo estão representadas pelas barreiras físicas como o revestimento epitelial, químicas como as secreções e biológicas tal como a fagocitose, os anticorpos, complemento e as enzimas da matriz extracelular.

Quando ultrapassam essa barreira, os microrganismos atravessam a parede dos vasos ficando sujeitos à segunda barreira podendo ser destruídos por fagocitose, enzimas plasmáticas, anticorpos e 
complemento. As bactérias podem ser impedidas também pela barreira física exercida pelas paredes dos vasos, cujas fenestrações são muito pequenas, dificultando sua saída para os tecidos.

Em alguns órgãos, os vasos são mais fenestrados, como no fígado, pulmão, rim, baço, mas estão revestidos por macrófagos, sendo importantes vias de eliminação dos microrganismos. No fígado estes macrófagos são denominados células de Kupffer.

Sobrevivendo, o microrganismo continua circulante até que encontre uma área que permita sua adesão e saída para os tecidos, o que se dá com maior freqüência em áreas previamente inflamadas, com vasos em permeabilidade aumentada, permitindo sua saída para os tecidos pelas fenestrações ampliadas. Novamente estão sujeitos aos fatores de defesa teciduais físicos, químicos e biológicos.

Nestes locais, quando sobrevivem, podem dar origem a um foco infeccioso secundário. Se encontrarem habitats propícios a sua proliferação nos tecidos previamente agredidos. Estes esconderijos podem estar representados por tecido necrótico, fragmentos de resina, raspas de dentina, resíduos de cimento obturador, guta-percha, frestas, fendas e fissuras encontradas entre o material obturador e a parede do canal radicular $^{60}$.

Esse processo pelo qual bactérias circulantes, pigmentos, substâncias metálicas, proteínas estranhas e outros materiais são atraídos e fixados em áreas de inflamação é denominado de anacorese ${ }^{59}$.

CSERNYEI $^{18}$ atribui a $\operatorname{ASCOL}^{5}$ (1937) a introdução do termo anacorese a partir do grego $\alpha \nu \alpha \chi \omega \rho \eta \delta 1 \xi$ significando convocação e também refúgio. Outro significado do grego: ato ou ação de retirar-se, retirada, refúgio. 
Na prática clínica diária, comumente ouve-se afirmações como:

- após a biopulpectomia a sintomatologia foi intensa e/ou houve agudescimento inclusive com formação de pus.

- após o dente ter sido traumatizado, sem fratura e comprometimento cervical periodontal, houve inflamação aguda do periápice com formação de pus ou lesão periapical crônica evoluindo para cisto periodontal apical.

Diante dessas afirmações e frente às seguidas implicações de procedimentos odontológicos com causa de endocardite infecciosa bacteriana e outras doenças resultantes de inflamações induzidas por bactérias via hematogênica como glomerulonefrites, uveítes e artrites poderse-ia questionar:

- há uma possibilidade de bactérias se instalarem nos ápices dentários após uma biopulpectomia?

- o grau de sintomatologia e as evoluções indesejáveis após uma biopulpectomia pode também ter relação com a fixação apical de bactérias via hematogênica?

A circulação pulpar assim como a circulação em outros locais, apesar de terminar arboriforme, sem circulação colateral, ainda assim é acessível a microrganismos como por exemplo o vírus da AIDS e bactérias, como demonstraram GLICK et al. ${ }^{26,27}$ e ABOUDHARAM et al. ${ }^{2}$. O grau de fenestrações dos vasos varia de órgão para órgão; a saída de bactérias em tecidos saudáveis é possível, mas se esses mesmos locais forem submetidos a um processo infamatório a chance da anacorese aumenta consideravelmente. Em tecidos saudáveis fica difícil questionar onde e como as bactérias evadiriam os mecanismos de defesa; provavelmente logo seriam eliminadas.

Os trabalhos de ABOUDHARAM et al. ${ }^{2}$ e DRANCOURT et al. ${ }^{21}$ procuraram caracterizar a polpa dentária como um santuário para 
recuperação de bactérias em corpos potencialmente contaminados, mesmo que estas polpas estivessem normais na época da morte do organismo. Caracterizada a polpa como um possível santuário de bactérias a serem recuperadas, poder-se-ia utilizá-la para recuperar microrganismos em procedimentos de valor legal e histórico. Este grupo de pesquisadores recuperou o DNA, via PCR (Polymerase Chain Reaction), de Yersinia pestis em esqueleto humano de um Francês morto a 400 anos do qual havia suspeita de ter sido levado a morte pela "peste negra".

A polpa dentária, por estar protegida, por tecidos duros e resistentes, até a altas temperaturas também é utilizada como santuário de DNA da própria espécie, e pode ser utilizada para identificar mortos em avançado ou completo estado de decomposição ou completamente queimados ${ }^{21}$.

A recuperação de protozoários parasitários instalados na polpa ou no periápice, por via hematogênica, não foi descrita ainda na literatura, quer em condições de normalidade ou como fenômeno anacorético. Diante de tal fato, questiona-se: sendo esses parasitas várias vezes maiores que as bactérias, o fenômeno anacorético, por eles protagonizado não seria uma manifestação exuberante de sua ocorrência nos tecidos dentários? Nesse sentido, a ocorrência de uma leishmaniose em cães, na região de Araçatuba, propiciou a oportunidade de se estudar simultaneamente, no mesmo modelo animal a anacorese bacteriana e parasitária. 
2 REVISÃO DA LITERATURA 
A anacorese na clínica odontológica e nas pesquisas aplicadas ainda foi pouco explorada. Isto levou a uma revisão da literatura que envolvesse desde os estudos pioneiros até os publicados nos dias atuais, abordados cronologicamente.

Preocupado com a probabilidade de áreas de inflamação exercerem poder de "atração" a microrganismos, CSERNYEI ${ }^{18}$, em 1939, realizou pulpectomia em dentes de cães que ficaram abertos ao meio bucal. Após algumas semanas os animais receberam injeção endovenosa com cultura de Bang bacilli (Brucella abortus). Três semanas após a bacteremia, os dentes foram extraídos, apicectomizados, colocados em solução fisiológica para separar os tecidos aderidos dos microrganismos e injetada em porquinho da Índia. Após três a quatro semanas, os animais foram sacrificados e realizados testes de aglutinação contra Bang bacilli apresentando resultado positivo e durante a necropsia detectourse esplenomeglia. Este experimento sugeriu que lesões periapicais crônicas têm efeito anacorético sobre microrganismos.

Em 1941, ROBINSON; BOLING ${ }^{59}$ realizaram avaliação bacteriológica em polpas de gatos de quatro formas:

- na série I, 30 cavidades foram preparadas em 11 animais, em 27 foi colocado óleo de cróton. Após 4 dias a 2 meses foi injetado endovenosamente $1 \mathrm{ml}$ de cultura de Streptococcus sp. Oitenta e dois por cento dos casos tratados apresentaram cultura positiva.

- na série II, de 10 cavidades preparadas, em $70 \%$ houve cultura positiva após a bacteremia provocada por Staphylococcus aureus.

- na série III, foram utilizados animais com infecção natural, e não induzida, encontrando $77 \%$ das cavidades com cultura positiva. 
- na série IV injetaram previamente Streptococcus sp. na corrente sangüínea de dois gatos. Após 1 e 8 dias houve ocorrência de culturas positiva em todos os dentes tratados.

Constatando a anacorese, os autores sugeriram que inflamações pulpares ocorrentes após longos períodos do tratamento dentário e classificadas como idiopáticas, deveriam receber o nome de "pulpite anacorética".

BURKE; KNIGHTON ${ }^{16}$, em 1960, realizaram preparos cavitários, com e sem exposição pulpar, em molares de ratos. Alguns dentes foram tratados com óleo de cróton, outros com OZE e todos restaurados com cimento de fosfato de zinco. Induziram bacteremia experimental, com suspensão de $2.10^{8}$ bactérias em BHI (caldo infuso de cérebro coração), através de inoculação endovenosa. Os animais foram sacrificados no primeiro e sétimo dia pós-bacteremia.

Dos dentes do grupo controle, $38 \%$ apresentaram cultura positiva para o período até 30 minutos, $12 \%$ após $24 \mathrm{~h}$ com cultura de sangue positiva e $2 \%$ com cultura de sangue negativa. Para o grupo teste, com pós-operatório de $24 \mathrm{~h}$, polpas expostas capeadas com óleo de cróton apresentaram $55 \%$ de casos com cultura positiva e sem exposição $30 \%$. Dentes com exposição apenas selados com cimento apresentaram mais resultado positivo que quando a exposição estava ausente. No tempo de 7 dias, apresentaram cultura positiva, $66 \%$ dos casos expostos tratados com óleo de cróton, enquanto que selados com cimento de 21,4 - 27,5\%. Polpas não expostas apresentaram cultura negativa. Quando a bacteremia foi realizada $24 \mathrm{~h}$ após os preparos cavitários, e estes tratados com óleo de cróton, $49 \%$ foi positiva. Sendo os dentes apenas capeados com cimento, 18-36\% positiva em polpas expostas. Quando a análise foi realizada após 7 dias, em polpas expostas, capeadas com óleo de cróton foi positivo em 2,6\% e $1,2 \%$ utilizando apenas cimento. Concluíram que os microrganismos foram localizados com maior freqüência nas polpas expostas e que quando o momento da bacteremia, ou sacrifício são tardios a incidência de culturas positivas se reduz. 
SMITH; TAPPE ${ }^{68}$, em 1962, avaliaram a contaminação de polpas de ratos utilizando um método asséptico de coleta de material pulpar. Obtiveram $33 \%$ de culturas positivas em dentes tratados com traumatismo oclusal, causado por um condensador pneumático, quando células de Corynebacterium sp. foram inoculadas imediatamente após o trauma com pós-operatório de 1 a 24 dias. Quando o trauma foi realizado por calor houve $59 \%$ de culturas positivas da polpa. Em dentes não traumatizados e quando o material foi colhido após 24 dias houve cultura negativa.

Empenhado em descobrir a origem dos microrganismos que colonizavam dentes traumatizados, GROSSMAN ${ }^{28}$, em 1967, desenvolveu modelo experimental em cães e macacos que tiveram o sulco gengival vestibular de dentes anteriores inoculado com Serratia marcescens, sendo os dentes artificialmente traumatizados. A bactéria estava presente em 6 dentes cuja polpa vital foi cultivada e também em 5 casos onde foram realizados culturas do canal logo após o trauma. Também exibiram cultura de canal positiva em 3 dentes após 14 e 21 dias e 1 após 35, 44 e 50 dias. As bactérias apareceram em fragmentos de polpa, em cães, até 54 dias. Nos macacos, foram recuperadas dos canais até 5 semanas do trauma, e no sangue em um caso imediatamente após o trauma.

A anacorese foi demonstrada experimentalmente em polpas de cães em 1968 por GIER; MITCHELL ${ }^{25}$. Nos dentes de quatro cães sadios prepararam cavidades classe $V$ sem exposição pulpar, mas expostas aos fluidos bucais ou capeadas com óleo de cróton e seladas com OZE. Três cães receberam injeção endovenosa de bactérias. Culturas positivas foram obtidas dos dentes expostos e capeados com óleo cróton. Cortes microscópicos foram analisados, verificando-se inflamação em vários graus e a ocorrência de necrose, sendo constatada presença de bactérias pela coloração de Brown e Brenn.

Em 1974, McGOWAN; HARDIE ${ }^{49}$ produziram endocardite bacteriana em coelhos preparados pela inserção de uma cânula no interior do coração e subseqüente manipulação bucal cirúrgica. A contaminação 
microbiana ocorreu em 15\% dos casos, estabelecendo que a endocardite pode ser originária de bacteremia por procedimentos intra-bucais.

Em 1975, SILVER et al. ${ }^{64}$ inocularam endovenosamente, em 12 cães, $1,3.10^{6}$ a $2.10^{7}$ UFC (unidade formadora de colônia) de Escherichia coli, Staphylococcus aureus, Streptococcus mitis, Corynebacterium sp. e "Bacteroides melaninogenicus" (atualmente reclassificados nos gêneros Prevotella e Porphyromonas). Culturas foram realizadas com amostras de sangue desde o pré-operatório imediato até 20 minutos após a bacteremia. A maior quantidade de bactérias foi recuperada após 30 segundos a 1 minuto da inoculação na maioria dos animais. A maior parte dos microrganismos deixava a circulação após 10 minutos e não era mais encontrada 20 minutos pós-inoculação.

Em cultura pré e pós-operatória, BAUMGARTNER et al. ${ }^{6}$, em 1977, avaliaram a ocorrência de bacteremia transitória em pacientes submetidos a cirurgia parendodôntica e exodontia simples. Os procedimentos parendodônticos causaram uma alta prevalência de bacteremia ( $59 \%$ dos casos) e todas exodontias, apresentaram bacteremia pós-operatória.

Em culturas sangüíneas de pacientes com gengivite após a escovação, SILVER et al. $^{65}$, em 1977, verificaram a ocorrência de bacteremia cuja percentagem de culturas positivas aumentava proporcionalmente à severidade da inflamação, variando de 35 a 57\%.

Em outro estudo, em 1979, SILVER et al. ${ }^{66}$ avaliaram a ocorrência de bacteremia após escovação em pacientes com gengiva sadia. Encontraram culturas positivas em 3 de 36 pacientes analisados.

Em pulpectomias de 13 pré-molares de 2 cães selados com OZE e amálgama, ALLARD; STRÖMBERG ${ }^{3}$, em 1979, realizaram culturas desses canais imediatamente, após 1, 2 e 3 meses. Uma hora e meia antes do sacrifício, os animais receberam injeção venosa de carbono coloidal. Apenas 1 canal, aos 3 meses, apresentou crescimento bacteriano. 
Microscopicamente foi observado discreto a moderado infiltrado inflamatório no periápice. Em várias raízes o carbono coloidal pode ser observado nos vasos, especialmente no delta apical. Concluíram que raízes pulpectomizadas não infectadas podem servir como região susceptível a infecção ou locus minoris resistentiae.

A ocorrência da anacorese foi sugerida por ALLARD et al. ${ }^{4}$ (1979) utilizando-se canais de dentes de cães submetidos a pulpectomia parcial ou total e preenchidos com cultura pura ou contendo Staphylococcus aureus, Streptococcus sanguis, Pseudomonas aeruginosa e Bacteroides fragilis. Em cada cão, apenas uma espécie de bactéria foi utilizada e os dentes selados. Foram realizadas culturas nos dentes não inoculados em intervalos de tempo variando de 4 a 120 dias e nos inoculados aos 50 e 100 dias. Isso foi adotado para avaliar a vitalidade dos microrganismos recuperados da maioria dos canais inicialmente não infectados; a coleta foi realizada após 28 a 120 dias. A análise microscópica revelou diferentes graus de inflamação dependendo do microrganismo inoculado. A presença das bactérias foi constatada pela coloração de Brown e Brenn.

Avaliando a influência do uso do fio dental na produção de bacteremia em pacientes com gengiva saudável, CARROLL; SEBOR ${ }^{17}$ (1980) realizaram culturas em quatro pacientes antes e após o seu uso. Os pacientes com uso diário do fio dental não desenvolveram bacteremia, mas $86 \%$ dos que deixaram de usar entre 1 a 4 dias desenvolveram-na.

A possibilidade de infecções pós-operatórias induzirem bacteremia em períodos curtos foi avaliada por BLOMGREN; LINDGREN ${ }^{8}$, em 1980, utilizando-se de um modelo animal. Defeitos ósseos foram realizados bilateralmente em coelhas, sendo de um lado preenchido com cimento ósseo acrílico. Os animais foram infectados com suspensão de Staphylococcus aureus localmente em ambos hematomas ou por via sangüínea. Houve uma distribuição semelhante da infecção de ambos os lados, tanto frente à inoculação local quanto pela via sistêmica. Os autores afirmaram: se ocorrer bacteremia em pós-operatórios recentes, há grande risco de contaminação por anacorese. 
Em polpas necróticas de macacos, assim induzidas de modo asséptico, MÖLLER et al. ${ }^{50}$, em 1981, mantiveram-nas seladas por 6 meses. Alguns canais foram mantidos expostos ao meio bucal por uma semana e posteriormente selados. Nenhum dos canais não infectados mostrou bactérias no final do experimento. Concluíram que o risco de contaminação de canal via anacorética em macacos é muito pequeno, embora tenha encontrado cepas bacterianas em períodos finais, nos dentes contaminados.

Para determinar se microrganismos circulantes poderiam ser atraídos e localizarem-se em canais radiculares instrumentados e não obturados, onde a circulação sangüínea não existe, DELIVANIS et al. ${ }^{20}$ (1981) instrumentaram canais de caninos de gatos, em seguida selados vazios, provocaram bacteremia pela injeção endovenosa de cultura contendo Bacillus subitilis, após 3 dias do preparo dos canais. Nas culturas dos canais realizadas $1 \mathrm{~h}$ e $48 \mathrm{~h}$ após a bacteremia não encontraram as bactérias inoculadas e relataram que o fenômeno da anacorese não foi evidenciado no modelo experimental.

A partir do estudo anterior, DELIVANIS, FAN ${ }^{19}$ (1984) utilizaram cinco gatos com caninos instrumentados e não obturados. Semanalmente, por um período de 2 meses, foi injetada suspensão de $7,5.10^{9}$ UFC de Streptococcus sanguis e realizado teste em cada canal uma vez por semana, todas apresentando culturas negativas. Após 2 meses, dois animais tiveram os ápices arrombados e sobreinstrumentados. Isso foi realizado imediatamente após uma bacteremia. Foram realizados testes bacteriológicos destes canais, após 3 dias, 1 e 2 semanas, obtendo-se culturas positivas para todos os períodos.

Ao avaliar a anacorese durante o período pós-operatório inicial, TZIAFAS $^{74}, 1989$, expôs 36 polpas de cães que foram capeadas com Dycal, $\mathrm{Ca}(\mathrm{OH})_{2}$ ou teflon. Aos 2, 14 e 28 dias 9 dentes tratados foram extraídos. Uma densa suspensão de estreptococos $\alpha$ hemolíticos foi inoculada por via venosa e os animais sacrificados $24 \mathrm{~h}$ após a bacteremia. As peças foram fixadas em formalina $10 \%$ e descalcificadas com ácido tricloroacético. Os cortes foram analisados em função da presença de bactérias, formação de 
tecido duro, resposta inflamatória e necrose. Foram observadas grande quantidade de bactérias até o período de 15 dias para todos o materiais testados. Aos 29 dias, houve ausência de bactérias em 3 casos capeados com teflon. Bactérias não foram encontradas no grupo controle, apenas dentro dos vasos sangüíneos pulpares e nos dentes extraídos antes da bacteremia.

Baseado no princípio de que a exodontia promove bacteremia e, por via anacorética, pode haver contaminação em órgãos internos, como pulmão, fígado e cérebro, LEE; KIM ${ }^{45}$, 1990, fizeram coleta de $10 \mathrm{ml}$ de sangue pré e pós-exodontia de 32 pacientes e incubaram em anaerobiose. Todos os pré-operatórios realizados apresentaram culturas negativas. Em $60 \%$ das amostras pós-operatórias houve culturas positivas para espécies anaeróbias obrigatórias e/ou facultativas.

Em levantamento de 138 casos de pacientes operados entre 1970 e 1987, WANG et al. ${ }^{76}, 1992$, relataram 8\% de abscesso intraabdominal após hepatectomia. Utilizando-se de ratos, promoveram hepatectomia parcial e verificaram bacteremia no período pós-operatório inicial. A contaminação de outros órgãos foi proporcional à quantidade de fígado removido.

Em ratos submetidos a queimaduras experimentais, MANSON et al. ${ }^{46}$, em 1992, investigaram a translocação bacteriana. Escherichia coli ( $10^{9}$ UFC) foram inoculadas no trato gastrintestinal. Alguns animais tiveram as feridas contaminadas com Pseudomonas aeruginosa, induzindo um aumento na prevalência da translocação de $E$. coli do trato gastrintestinal para fígado, pulmão, baço e cavidade peritonial no $2^{\circ}$ e $3^{\circ}$ dia. Ocorreu também disseminação de $P$. aeruginosa por via hematogênica.

Após a inoculação de bactérias na corrente sangüínea de ratos, HIRAKATA et al. ${ }^{30}$, em 1993, avaliaram o tempo que os vários microrganismos testados permaneciam no sangue e verificaram que após 30 minutos a maior parte das bactérias havia desaparecido da corrente sangüínea. 
HIRAKATA et al. ${ }^{31}$, em 1996, estabeleceram um modelo animal experimental capaz de reproduzir a septicemia causada por Klebsiella pneumoniae e Escherichia coli. Com a aplicação de agente imunossupressor em ratos foi observada septicemia nos animais que tiveram bactérias inoculadas no trato gastrintestinal por via bucal.

Para caracterizar o potencial patogênico de uma cepa de Borrelia sp. isolada de um cão, BREITSCHWERDT et al. ${ }^{14}$, em 1996, injetaram inóculos crescentes desta bactéria no peritônio de ratos e porquinho da Índia. Com quatro dias pós-operatório, dois ratos tratados foram necropsiados e realizadas culturas dos tecidos e sangue. Um rato receptor foi inoculado com sangue contaminado. Por 48 dias os porquinhos da Índia foram avaliados clínica, hematológica e microbiologicamente e necropsiados. Nos ratos, foi detectada bacteremia aos 3 e 13 dias. Os porquinhos da Índia não apresentavam sinais de doença e alterações hematológicas apesar de serem isoladas espiroquetas do sangue após o sétimo dia. Quando necropsiados foram observadas alterações como hiperplasia linfóide e epicardite.

Ratos Wistar foram utilizados por KITADA et al. ${ }^{44}$, em 1997 , para indução de endocardite experimental pela inserção de um catéter na artéria carótida direita até o ventrículo esquerdo. Após 24 horas, os animais foram infectados com uma injeção endovenosa de $0,5 \mathrm{ml}$ do inóculo contendo $5.10^{8}$ UFC de 8 isolados de Streptococcus anginosus, 5 isolados de Streptococcus constellatus, 5 isolados de Streptococcus intermedius e Streptococcus oralis. Após 3 dias, amostras de sangue eram colhidas e os animais sacrificados. A indução de endocardite foi diferente para as bactérias utilizadas. Os Streptococcus anginosus apresentaram culturas positivas em $93 \%$ dos casos. Os Streptococcus intermedius causaram endocardite apenas em $23,3 \%$. Achados microscópicos confirmaram os resultados das culturas.

YAO et al. ${ }^{79}$, em 1997, traçaram um paralelo entre achados microscópicos, microbiológicos e a expressão de citocinas num modelo de sepse experimental, por meio de injeção venosa de $S$. aureus em ratos 
Webster. O sangue apresentou-se com ausência de bactérias às 72 horas. Células inflamatórias foram inicialmente observadas no interior dos vasos e nos tecidos adjacentes. Outras alterações incluindo edema intersticial, formação de microagregados de leucócitos no parênquima e necrose tecidual foram encontrados a partir de 48 horas. Em súmula, a magnitude da inflamação aumentou com o tempo.

Com a finalidade de comprovar a colonização da polpa dentária sadia por bactérias advindas da corrente sangüínea, ABOUDHARAM et al. ${ }^{2}$, em 2000, inocularam porquinhos da Índia, intraperitonialmente, com Coxiella burnetii. Após 0, 5, 10, 15 e 20 dias os animais eram sacrificados, os dentes extraídos e armazenados em PBS estéril por 8 dias para eliminação de todo sangue, a polpa removida apicalmente e processada. Os resultados demonstraram presença da bactéria no tecido pulpar pelo método PCR (Polymerase Chain Reaction), após 15 dias. Chamaram atenção para o fato de mesmo polpas sãs poderem servir de reservatório de DNA de microrganismos para identificação futura. 
3 PROPOSIÇÃO 
A partir das observações resgatadas na literatura e dos questionamentos abordados na introdução, em cães em região endêmica para leishmaniose, propusemo-nos a:

3.1. avaliar a ocorrência de anacorese em periápice de dentes de cães com canais obturados em diferentes níveis;

3.2. analisar a ocorrência de anacorese após 48 horas de bacteremia experimental e a persistência destes microrganismos após 30 dias através da cultura tecidual e análise microscópica;

3.3. analisar a distribuição das bactéria nos tecidos apicais e periapicais, após anacorese, utilizando a microscopia óptica. 
4 MATERIAL E MÉTODOS 
Todos os procedimentos foram considerados de acordo com os Princípios Éticos na Experimentação Animal adotado pelo Colégio Brasileiro de Experimentação animal (COBEA) e aprovados pela Comissão de Ética na Experimentação Animal (CEEA-FOA) em reunião de 10 de agosto de 1999.

\subsection{Trabalho experimental}

Cento e quatro raízes de incisivos (24) e pré-molares (80) de 4 cães foram utilizadas para este experimento. Os animais apresentavam exames sorológicos negativos para Leishmaniose.

Os animais foram pré-anestesiados com Acepran (Bayer S/A Produtos Veterinários - Ind. Bras., RS) e Ketamina (Parke - Davis - Achê Laboratórios Farmacêuticos S/A Ind. Bras., SP) intramuscular, na proporção de $1: 1 \mathrm{ml}, 30$ minutos antes do ato operatório.

A anestesia geral foi obtida com solução endovenosa de Nembutal Sódio à 3\% (Hypnol - Cristália Produtos Químicos Farmacêuticos Ltda.), na dosagem de $1 \mathrm{ml}$ por quilograma de massa corpórea. Quando necessário, essa dosagem foi suplementada para manter 0 efeito anestésico. Em seguida, os animais foram entubados, com auxílio de um Laringoscópio Ref. 400 com fibra óptica (Kole Equimed) para colocação de uma sonda endo-traqueal ก.. 28, modelo Rusch com Cuff (Rep. Fed. Alemanha). Durante todo o período operatório, e aproximadamente 30 minutos após a sua conclusão, os animais receberam, também por via endovenosa, solução de glicose à $5 \%$ (Laboratório J.P. - Indústria Farmacêutica S.A.).

Os dentes receberam polimento coronário, foram isolados com lençol de borracha e feita anti-sepsia do campo operatório com solução alcoólica iodetada a $0,3 \%$. 
Inicialmente procedeu-se a abertura coronária com pontas esféricas diamantadas, movimentadas em alta rotação, refrigeradas a ar/água, sendo depois substituídas pelas brocas Endo-Z (Dentsply/Maillefer - Suíça). Todo o instrumental e material utilizados nos procedimentos foram previamente esterilizados em autoclave a $134^{\circ} \mathrm{C}$, por 15 minutos.

Foram efetuadas as pulpectomias até o platô apical, com o auxílio de extirpa nervos, de diâmetro compatível com o canal radicular.

A seguir foi procedido o preparo biomecânico com o emprego de ampliadores de orifício, brocas Gates-Gliden, limas tipo Kerr e tipo Hedstrom (Maillefer - Suíça), segundo a técnica de preparo biomecânico da Disciplina de Endodontia de Araçatuba - UNESP (Mista Invertida ${ }^{38}$ ). Durante todo o preparo biomecânico, foram realizadas irrigações, $3 \mathrm{ml}$ de solução a cada troca de instrumento, com hipoclorito de sódio a $1 \%(\mathrm{NaOCl}$ - solução de Milton Biodinâmica Química e Farmacêutica Ltda.).

Concluído o preparo biomecânico (lima tipo Kerr n.. 40 em toda extensão do canal e tipo Hedstrom com recuo natural e progressivo até o instrumento de $\mathrm{n} .{ }^{\circ} 60$ ), os canais radiculares foram irrigados novamente com solução de Milton. Posteriormente realizourse o arrombamento do forame apical com uma lima tipo Kerr $\mathrm{n}$. - 20, acrescentando-se 1,5mm além da odontometria. A seguir, os canais radiculares foram irrigados, aspirados e secos com auxílio de cones de papel absorvente estéreis e selecionados os cones principais de guta-percha.

Os canais foram obturados pela técnica da condensação lateral, com cimento de Óxido de Zinco e Eugenol (S.S. White), manipulado numa consistência tal que formasse um fio de aproximadamente $2 \mathrm{~cm}$ quando a espátula fosse elevada da placa de vidro, e levado para o interior do canal radicular com o cone principal. Metade dos canais preparados foram obturados no limite de manipulação, na outra metade foi realizada sobreobturação, utilizando-se um cone principal de guta percha que ultrapassasse em $1 \mathrm{~mm}$ o limite de trabalho. 
No momento da obturação levou-se o cone principal de guta percha untado em cimento e, para o grupo de sobreobturação, realizava-se movimento de entrada e saída deste cone do canal. O cone era então untado novamente com cimento e levado em posição no canal.

Concluída a obturação e a limpeza da câmara pulpar as aberturas coronárias foram seladas com uma camada de aproximadamente $1 \mathrm{~mm}$ de espessura de Coltosol (coltene - Suíça) e restauradas com amálgama de prata. Todos os procedimentos foram anotados em fichas (Figura 1).

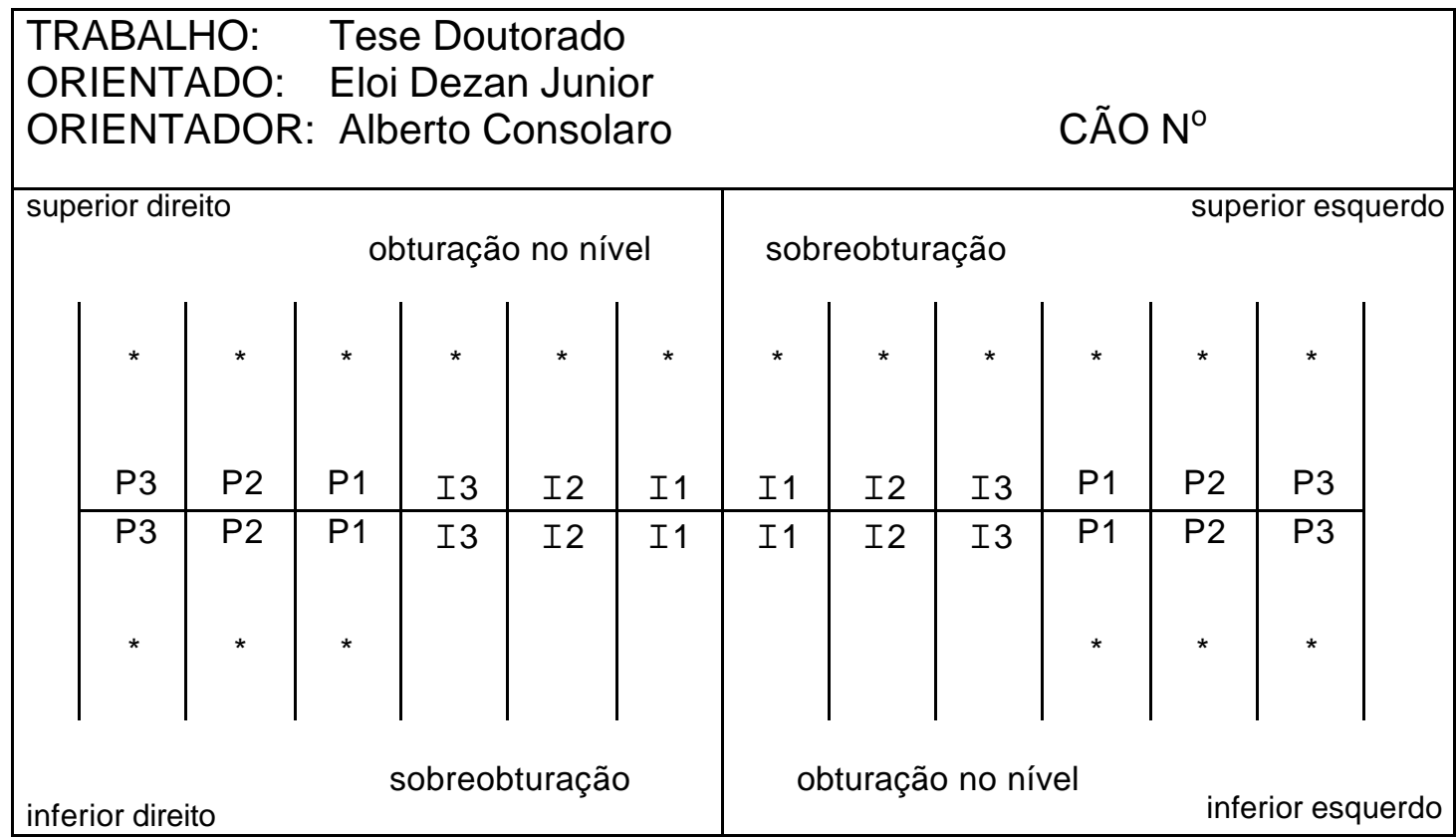

FIGURA 1 - Modelo de ficha para trabalho em cão utilizado para anotar detalhes no trans-operatório dos dentes a serem tratados $\left(^{*}\right)$. (I) incisivo, ( $\mathrm{P}$ ) pré-molar

\subsection{Microrganismo}

\subsubsection{Obtenção do microrganismo}

Após 120 dias do tratamento endodôntico, os animais foram inoculados por via endovenosa com uma cepa de Streptococcus pyogenes (MOA 85) obtido de caso clínico de amigdalite, pertencente ao banco de 
microrganismos da Disciplina de Microbiologia da Faculdade de Odontologia de Araçatuba - UNESP, onde todos os procedimentos microbiológicos foram realizados.

A identificação da espécie do microrganismo foi realizada avaliando-se suas características bioquímico-fisiológicas e morfológicas ${ }^{41}$.

$O$ isolado de $S$. pyogenes empregado mostrou possuir resistência à penicilina $G$, ampicilina e eritromicina, sendo altamente sensível à lincomicina e cefoxitina. A sensibilidade do isolado testado a essas drogas foi determinada pelo método da diluição da droga em ágar ${ }^{72}$. $O$ meio de cultura usado foi o ágar infuso de cérebro coração acrescido de $0,5 \%$ de extrato de levedura. A concentração inibitória mínima para cada antimicrobiano foi definida como a menor concentração da droga que inibiu totalmente o crescimento bacteriano nas placas teste (com antimicrobianos) em relação às placas controle (sem droga). Nos testes para avaliar o perfil de resistência do $S$. pyogenes, o inóculo final de aproximadamente $10^{5}$ células bacterianas/botão foi transferido com o auxílio de replicador de Steers. A leitura dos testes foi realizada após incubação das placas em dessecadores de vidro tipo "Pyrex", em microaerofilia pela técnica da chama de vela, a $37^{\circ} \mathrm{C}$, por 48 horas.

Para inoculação dos microrganismos nos animais experimentais, aqueles eram cultivados em caldo de tripticaseína de soja, em microaerofilia, a $37^{\circ} \mathrm{C}$, por 48 horas, até atingir a turbidez correspondente à $10^{9} \mathrm{UFC} / \mathrm{ml}$.

A seguir as células bacterianas eram submetidas a centrifugação a 3000rpm por cinco minutos e lavadas, sucessivamente, pelo mesmo processo, com solução salina fosfatada tamponada (PBS), para remoção dos resíduos de meio de cultura. As células bacterianas eram, então, ressuspendidas em PBS até a concentração de $5 \times 10^{6}$ bactérias $/ \mathrm{ml}$. 


\subsubsection{Inoculação nos animais experimentais}

Os animais foram sedados com Acepran e Ketamina, realizada anti-sepsia com álcool iodado $2 \%$, então os microrganismos inoculados endovenosamente, através da veia cefálica. $\mathrm{O}$ inóculo utilizado foi de $5.10^{6}$ bactérias $/ \mathrm{ml}$, num total de $4 \mathrm{ml}$ por animal.

Durante todo o tempo experimental os animais ficaram alojados em celas especiais limpas e arejadas, recebendo alimentação balanceada (ração para cães Dink Dog-produtor/Moinho Primor-São Paulo/SP) e água potável ad libitum sendo inspecionados semanalmente até o momento do sacrifício, realizado com excesso de anestésico.

\subsection{Remoção das peças teciduais}

Após o sacrifício dos animais experimentais, decorridos 48 horas e 32 dias da inoculação do microrganismo teste, procedeu-se a remoção das peças teciduais para análise microscópica pelo método de Brown \& Brenn e cultura microbiana.

Previamente à remoção das peças teciduais, procedeu-se a descontaminação do campo operatório realizando-se anti-sepsia intra e extrabucal com polivinilpirrolidona iodada com $1 \%$ de iodo ativo (Povidine).

A remoção das peças foi realizada com auxílio de instrumentais manuais e rotatórios previamente esterilizados. Os fragmentos teciduais removidos consistiam, aproximadamente, dos $5 \mathrm{~mm}$ mais apicais das raízes dos dentes superiores e inferiores testados e dos tecidos periodontais adjacentes mineralizados ou não.

As peças enviadas para o processamento laboratorial com finalidade de análise microscópica foram transferidas para frascos contendo $100 \mathrm{ml}$ de solução de formalina a $10 \%$ tamponada em pH neutro, enquanto aquelas enviadas a recuperação do microrganismo inoculado foram 
acondicionadas em tubos contendo $5 \mathrm{ml}$ de caldo de tioglicolato, o qual atuou como meio de transporte.

\subsection{Recuperação do microrganismo inoculado}

Oito raízes de cada período foram encaminhadas para análise microbiológica.

Inicialmente procedeurse a maceração das peças teciduais. A seguir os fragmentos foram transferidos para tubos contendo $5 \mathrm{ml}$ de caldo de tripticaseína de soja acrescido de $0,5 \%$ de extrato de levedura e para placas contendo ágar de tripticaseína de soja acrescido de 0,5\% de extrato de levedura e enriquecido com $5 \%$ de sangue desfibrinado de cavalo.

Os tubos e as placas foram incubados em condições de microaerofilia, em dessecadores de vidro, a $37^{\circ} \mathrm{C}$, por 48 horas. Caso não houvesse crescimento bacteriano, os tubos e placas permaneciam incubados por até 10 dias, após o que eram descartados.

\subsection{Confirmação da identidade do microrganismo recuperado}

Para verificar se o microrganismo recuperado correspondia ao inoculado previamente por via endovenosa realizou-se uma analise morfológica (método de Gram) seguida de uma análise bioquímicofisiológica, a qual poderia confirmar que tanto o microrganismo recuperado quanto o inoculado pertenciam a uma única espécie ${ }^{41}$.

Para se comprovar a identidade dos microrganismos recuperados, os mesmos foram submetidos a testes para se determinar a concentração inibitória mínima (CIM) de penicilina G, ampicilina, lincomicina, eritromicina e cefoxitina como já descrito anteriormente, uma vez que o perfil de suscetibilidade do microrganismo inoculado já era conhecido. 


\subsection{Preparo para análise microscópica}

\subsubsection{Fixação}

As peças enviadas para o processamento laboratorial com finalidade de análise microscópica foram transferidas para frascos contendo $100 \mathrm{ml}$ de solução de formalina a 10\% tamponada em pH neutro, permanecendo por um período mínimo de 72 horas.

\subsubsection{Desmineralização}

Após a fixação, as peças foram transferidas para recipientes de plástico para a desmineralização em solução de ácido etilenodiaminotetracético a 5\% tamponado em $\mathrm{pH} 7,0^{77,78}$, mantida a uma temperatura de $40^{\circ} \mathrm{C}$ e renovada duas vezes por semana. Considerou-se finalizado o processo de desmineralização quando as peças apresentavamse com consistência borrachóide, sem resistência à penetração de uma agulha fina e radiotransparentes à ondas de raios $X$.

\subsubsection{Inclusão e microtomia}

As peças foram lavadas em água corrente por $24 \mathrm{~h}$, desidratadas em álcool, diafanizadas em xilol e incluídas em parafina.

Cortes seriados com $6 \mu \mathrm{m}$ de espessura foram obtidos de cada espécime iniciados após a obtenção de um corte que evidenciasse a luz do canal no seu longo eixo.

\subsubsection{Coloração}

Todos os cortes obtidos foram corados pela técnica de Brown e Brenn para avaliação microscópica. 


\subsection{Análise microscópica}

Durante a leitura das lâminas os resultados foram expressos em tabelas previamente elaboradas, exemplificada na Figura 2.

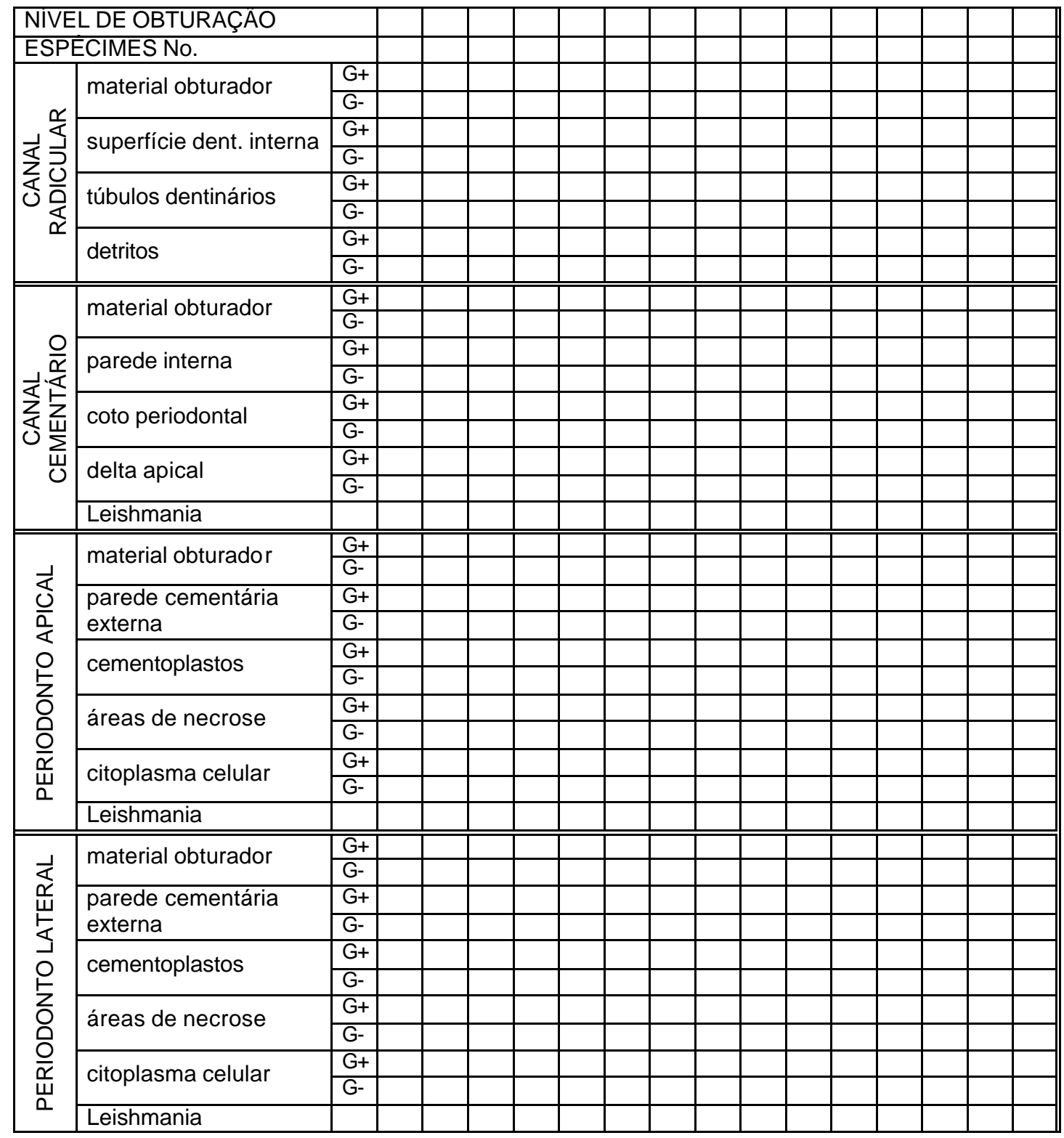

FIGURA 2 - Tabela utilizada para anotar os resultados obtidos pela análise microscópica. G + Gram positivo, G - Gram negativo

Inicialmente determinourse o limite apical da obturação dos canais atribuindo-se classificação em conformidade com os valores expressos na Figura 3, baseado em trabalho de PANZARINI ${ }^{55}$. 


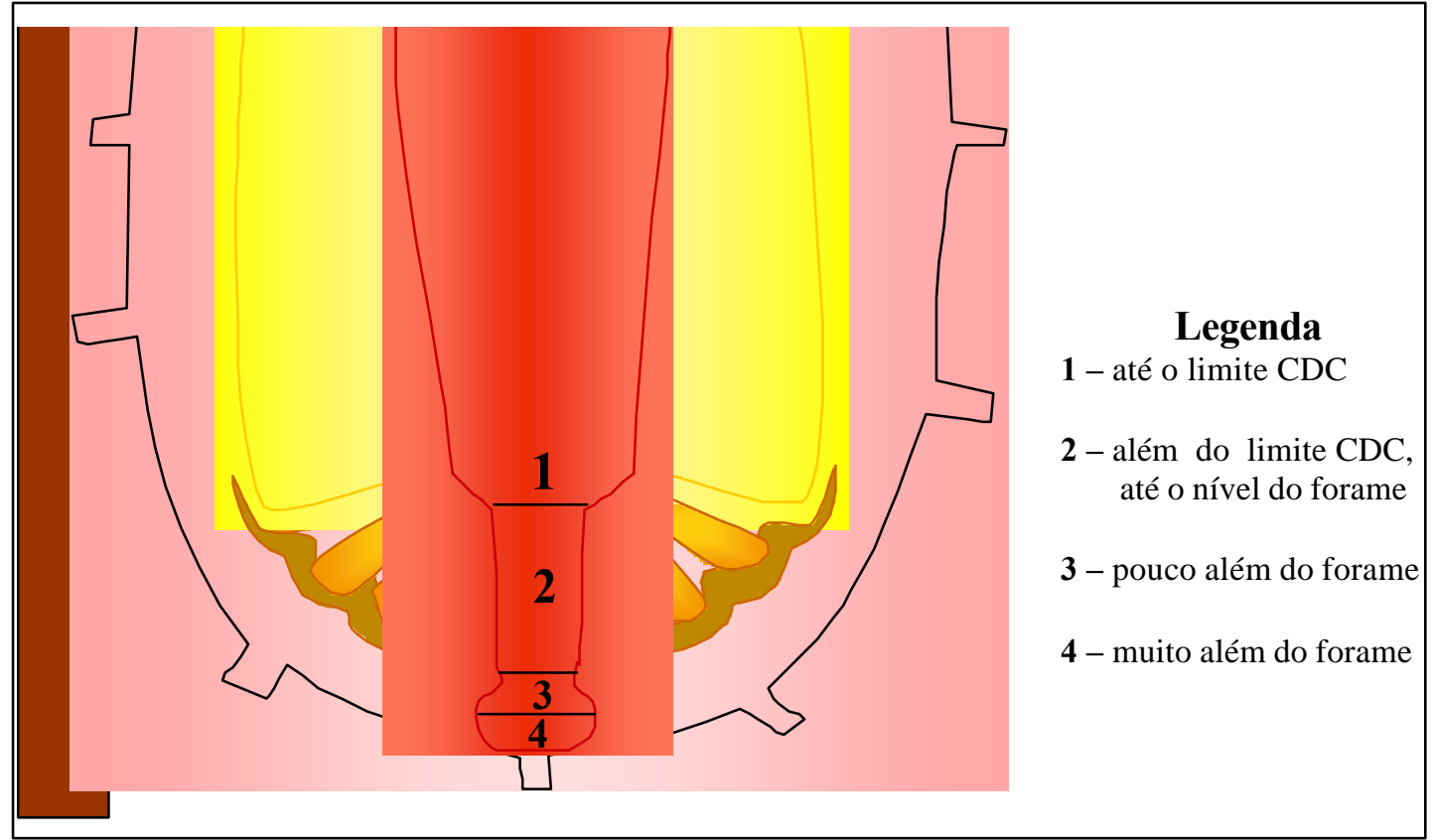

FIGURA 3 - Representação esquemática dos limites da obturação do canal radicular do cão

Na seqüência, com objetiva de imersão, fram avaliados os seguintes aspectos: presença, distribuição e localização de bactérias Gram positivas e Gram negativas no interior do canal principal, canal cementário e delta apical, periodonto apical e periodonto lateral conforme representado na Figura 4.

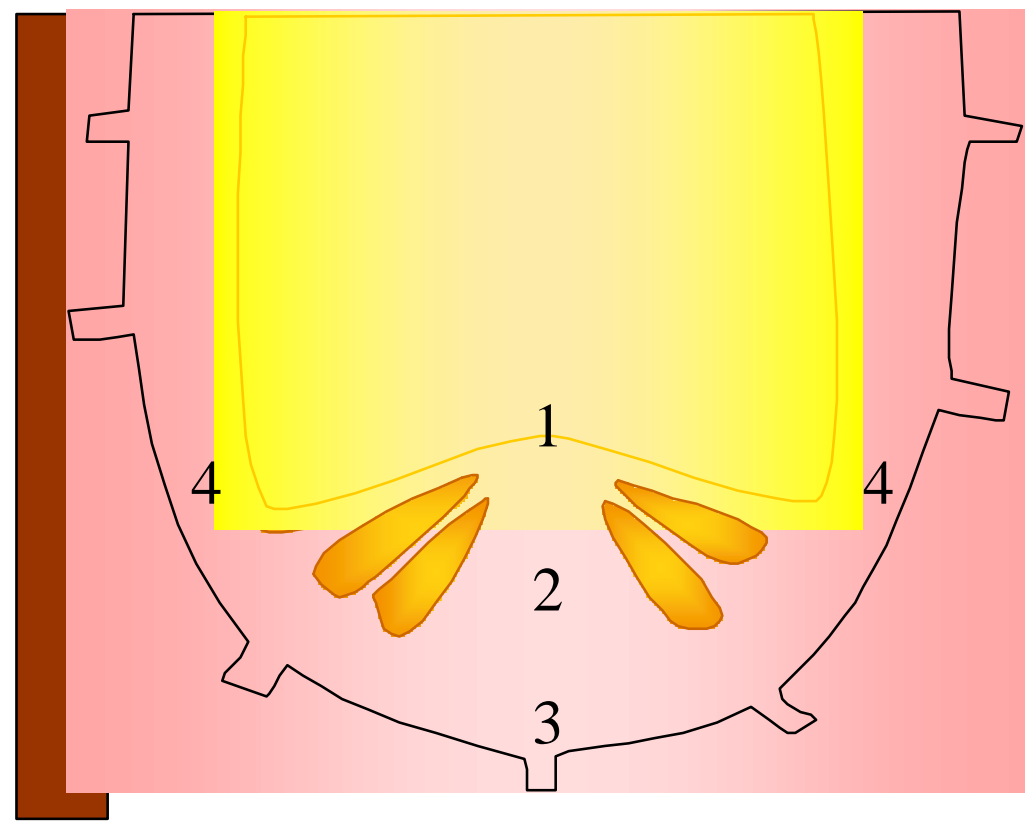

$$
\begin{aligned}
& \text { Legenda } \\
& \text { 1 - canal radicular } \\
& \text { 2 - canal cementário e } \\
& \text { delta apical } \\
& \text { 3- periodonto apical } \\
& \text { 4- periodonto lateral }
\end{aligned}
$$

FIGURA 4 - Representação esquemática das regiões analisadas ao microscópio óptico para identificação de bactérias 


\section{RESULTADOS}


5.1

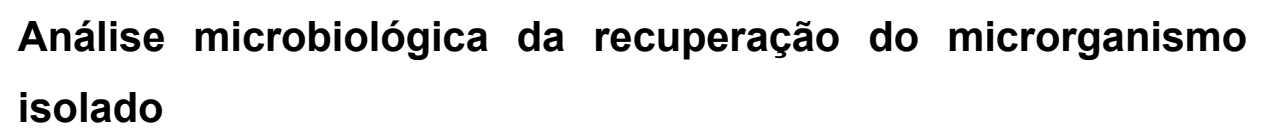

O resultado dos procedimentos empregados para a implantação do microrganismo inoculado foram considerados satisfatórios, a partir da recuperação do mesmo de dois animais experimentais após 48 horas de inoculação.

A Tabela 1 traz as concentrações inibitórias mínimas para as 5 drogas testadas frente ao microrganismo inoculado nos animais experimentais e frente ao recuperado destes após o sacrifício. Os testes de suscetibilidade e as demais características bioquímico-fisiológicas do microrganismo recuperado da região periapical sugerem que o mesmo seja idêntico ao inoculado por via endovenosa.

TABELA 1 - Concentração inibitória mínima (CIM) para a cepa de $S$. pyogenes inoculada nos animais experimentais e para aquela recuperada 48 horas após a inoculação

\begin{tabular}{lcc}
\hline \multicolumn{1}{c}{ Agente } & \multicolumn{2}{c}{ CIM $(\mu \mathrm{g} / \mathrm{ml})$} \\
antimicrobiano & $\begin{array}{c}\text { S. pyogenes } \\
\text { inoculado }\end{array}$ & $\begin{array}{r}\text { S. pyogenes } \\
\text { Recuperado }\end{array}$ \\
\hline Ampicilina (Amp) & $32(\mathrm{R})^{1}$ & $32(\mathrm{R})$ \\
Cefoxitina (Cf) & $0,5(\mathrm{~S})^{2}$ & $0,25(\mathrm{~S})$ \\
Eritromicina (Er) & $128(\mathrm{R})$ & $64(\mathrm{R})$ \\
Lincomicina (Li) & $0,25(\mathrm{~S})$ & $0,25(\mathrm{~S})$ \\
Penicilina G (Pe) & $64(\mathrm{R})$ & $32(\mathrm{R})$
\end{tabular}

Pontos críticos adotados* $(\mu \mathrm{g} / \mathrm{ml})$ : Amp, 16; Cf, 32; Er, 16; Li, 16; Pe, 16.

$1(\mathrm{R})$ resistente

2 (S) susceptível

* ponto crítico é o nível de maior concentração que a droga atinge no sangue do com finalidade terapêutica, a partir desta dosagem torna-se tóxico 
A presença de microrganismos contaminantes foi discreta e associada à manipulação das peças até o processamento microbiológico ou à instalação de microrganismos exógenos.

Em placa de ágar sangue, observourse elevada quantidade de colônias da bactéria teste e quase ausência de contaminantes, sugerindo que o estabelecimento da infecção foi bem sucedido e a remoção da peça não acarretou contaminação adicional significativa ou desorganização das colônias que o microrganismo teste produziu na região periapical.

Nos animais sacrificados 30 dias após a inoculação experimental, observou-se um grande aumento na contaminação da região periapical, sendo que pela análise morfocelular desses isolados constatour se a presença de uma microbiota mista constituída por numerosos cocos Gram positivos e bastonetes, mais raros, Gram negativos. Dentre os cocos Gram positivos isolados, nenhum apresentou as características fenotípicas do microrganismo teste inoculado e acabaram sendo descartadas.

Nos animais sacrificados após 30 dias da inoculação experimental, não foi possível recuperar o microrganismo teste da região periapical.

Nos cães sacrificados após 48 horas da inoculação foi possível recuperar a bactéria teste. Contudo, apenas metade dos espécimes de cada animal produziram resultados positivos, sendo que em uma dessas amostras de tecido periapical a presença da bactéria teste foi da ordem de $10^{3}-10^{4}$ bactérias (Tabela 2). Os isolados de Streptococcus pyogenes obtidos de cada cão se mostraram similares. Em um dos animais, além da bactéria testada, foram isolados outros microrganismos, mas em níveis modestos. No outro animal a bactéria testada instalou-se como monoinfecção. 
TABELA 2- Presença de positividade do S. pyogenes em culturas das raízes nos tempos experimentais

\begin{tabular}{cccc}
\hline $\begin{array}{c}\text { Tempo pós } \\
\text { bacteremia }\end{array}$ & $\begin{array}{c}\text { Raízes } \\
\text { analisadas }\end{array}$ & Número & $\%$ \\
\hline $48 \mathrm{~h}$ & 8 & $4^{*}$ & 50 \\
$30 \mathrm{~d}$ & 8 & 0 & 0 \\
\hline
\end{tabular}

* Este número corresponde a 2 raízes em cada animal experimental

\subsection{Análise microscópica}

\subsubsection{Observações relativas à morfologia}

Foram observados 19 casos com obturação nível 1 para os espécimes avaliados $48 \mathrm{~h}$ após a bacteremia que caracterizavam-se principalmente pela presença de periodonto lateral com características de normalidade. O periodonto apical apresentava-se com aspecto de normalidade em alguns casos, enquanto que em outros havia ocorrência de infiltrado inflamatório mononuclear e/ou, algumas vezes, polimorfonuclear, de pequena intensidade. O canal cementário apresentava-se ora com, ora sem tecido conjuntivo periodontal até o nível mais apical da obturação, podendo apresentar deposição lateral de cemento neoformado. Em um caso foi observada grande invaginação de tecido conjuntivo para o interior do canal radicular ocupando espaço vazio deixado pela obturação deficiente. Tal tecido na sua extremidade mais coronária apresentava infiltrado inflamatório mononuclear.

Normalmente os canais radiculares apresentavam paredes regularizadas pela instrumentação. Os deltas apicais usualmente estavam ocupados por tecido conjuntivo organizado e os cementócitos presentes. 
Os 3 casos com obturação nível 2 apresentavam tecido conjuntivo organizado em contato com o material obturador com algumas células inflamatórias presentes em pequena intensidade. Um dos casos apresentava tecido invaginado para 0 interior do canal entre o material obturador e a parede do canal com presença de infiltrado inflamatório de pequena intensidade e também pequeno espessamento do periodonto apical.

Casos com sobreobturação nível 3 apresentavam o material obturador extravasado envolto por cápsula fibrosa e, em determinados locais em contato com infiltrado inflamatório tipo mononuclear. Estes quadros foram caracterizados por um aumento da espessura do periodonto apical. Além disso podiam ser vistos alguns macrófagos com partículas de cimento fagocitadas ao redor do material obturador extravasado.

$\mathrm{Na}$ ocorrência de grande extravasamento de material para o periodonto apical, nível 4 de obturação, ocorria grande aumento da espessura do ligamento periodontal o qual exibia maior número de macrófagos com partículas de cimento fagocitadas por todo o periodonto apical, ora estendendo-se lateralmente. As fibras colágenas apresentavamse mais desorganizadas.

Os espécimes avaliados 30 dias após a bacteremia com nível 1 de obturação apresentavam resultados bastante homogêneos com característica de normalidade do periodonto apical. Vários casos apresentavam indícios de reparação por deposição de cemento neoformado nas paredes laterais do canal cementário. Algumas vezes essa deposição englobava resíduos decorrentes da instrumentação. Em um caso foi observado reparo junto ao canal principal, aliado à presença de inflamação próxima a um canal do delta.

O único caso com nível 2 de obturação apresentava tecido conjuntivo organizado em contato com o material obturador. 
O nível 3 de obturação apresentou características semelhantes às observadas para o período de 48 horas.

A maior desorganização do periodonto apical foi proporcionada pelos 3 casos nível 4.

\subsubsection{Observações relativas à presença e localização das bactérias}

O canal radicular, englobando material obturador, superfície dentinária interna e túbulos dentinários estavam isentos de bactéria, independentemente do nível de obturação.

As Figuras 5 a 9 ilustram a localização das bactérias nos períodos estudados.

No período de 48h após a bacteremia, bactérias estavam presentes em $46,88 \%$ dos espécimes (Tabela 3 ).

TABELA 3- Raízes com anacorese experimental após 48 horas da bacteremia. Classificação quanto ao nível da obturação

\begin{tabular}{cccc}
\hline $\begin{array}{c}\text { Nível da } \\
\text { obturação }\end{array}$ & $\begin{array}{c}\text { Número de } \\
\text { raízes }\end{array}$ & Número & $\%$ \\
\hline 1 & 19 & 12 & 63,16 \\
2 & 3 & 0 & 0 \\
3 & 4 & 1 & 25,00 \\
4 & 6 & 2 & 33,33 \\
\hline Total & 32 & 15 & 46,88 \\
\hline
\end{tabular}


No canal cementário foram observadas bactérias aderidas a detritos e no cemento depositado na parede lateral. Esses microrganismos foram também observados no coto periodontal junto a detritos e no citoplasma de macrófagos. Os deltas apicais apresentaram casos positivos em detritos e no citoplasma celular.

No periodonto apical e lateral verificou-se bactérias fagocitadas por macrófagos e no interior e adjacências de alguns vasos sangüíneos.

A distribuição das ocorrências de bactérias para o período de 48h encontra-se na Tabela 4 e anexo 1.

TABELA 4- Localização das bactérias na anacorese experimental 48h após bacteremia

\begin{tabular}{clc}
\hline \multicolumn{2}{c}{ Região anatômica } & Número de casos \\
\hline $\begin{array}{c}\text { Canal } \\
\text { cementário }\end{array}$ & coto periodontal interna & 2 \\
& delta apical & 5 \\
\hline $\begin{array}{c}\text { Periodonto } \\
\text { apical }\end{array}$ & citoplasma celular & 5 \\
\hline $\begin{array}{c}\text { Periodonto } \\
\text { lateral }\end{array}$ & citoplasma celular & 5 \\
\hline & Total & $21^{*}$ \\
\hline
\end{tabular}

* Em alguns casos as bactérias foram identificadas em mais de um local 
Nos animais avaliados 30 dias após a bacteremia foram observadas bactérias em $28,12 \%$ das raízes, Tabela 5 .

TABELA 5- Raízes com anacorese experimental após 30 dias da bacteremia. Classificação quanto ao nível da obturação

\begin{tabular}{cccc}
\hline $\begin{array}{c}\text { Nível da } \\
\text { obturação }\end{array}$ & $\begin{array}{c}\text { Número de } \\
\text { raízes }\end{array}$ & \multicolumn{2}{c}{ Presença de bactérias } \\
número & $\%$ \\
\hline 1 & 23 & 6 & 26,09 \\
2 & 1 & 1 & 100,00 \\
3 & 5 & 1 & 20,00 \\
4 & 3 & 1 & 33,33 \\
\hline Total & 32 & 9 & 28,12 \\
\hline
\end{tabular}

Foram observadas bactérias em detritos do canal radicular, na parede interna do canal cementário, nas ramificações do delta apical, inclusive fazendo parte da barreira do selamento apical.

O periodonto lateral, de 3 raízes, alojava bactérias no interior do citoplasma de macrófagos.

A distribuição das ocorrências para o período de 30 dias pode ser vista na Tabela 6 e Anexo 2. 
TABELA 6- Localização das bactérias na anacorese experimental 30 dias após a bacteremia

\begin{tabular}{clc}
\hline \multicolumn{2}{c}{ Região anatômica } & Número de casos \\
\hline Canal radicular & detritos & 1 \\
\hline $\begin{array}{c}\text { Canal } \\
\text { cementário }\end{array}$ & parede interna & 1 \\
coto periodontal & 4 \\
lateral & citoplasma celular & 5 \\
\hline & Total & 3 \\
\hline
\end{tabular}

* Em alguns casos as bactérias foram identificadas em mais de um local

\subsection{Observações relativas à presença e localização de} Leishmania sp. (Figuras 6A, 10 e 11)

Dois animais apresentavam sinais microscópicos da presença de leishmania, ambos do período de 48h pós-bacteremia. Em um deles foi constatada em 10 das 16 raízes analisadas, no segundo em 2 das 16 (anexos 1 e 2). Normalmente os protozoários estavam no interior de macrófagos espalhados ou aglomerados pelo periodonto apical em 11 de 12 , no periodonto lateral em 4 de 12 nos casos de sobreobturação. Em um caso apresentava-se no tecido periodontal invaginado para o interior do canal. Nos animais sacrificados 30 dias depois da bacteremia, não foram observados. 


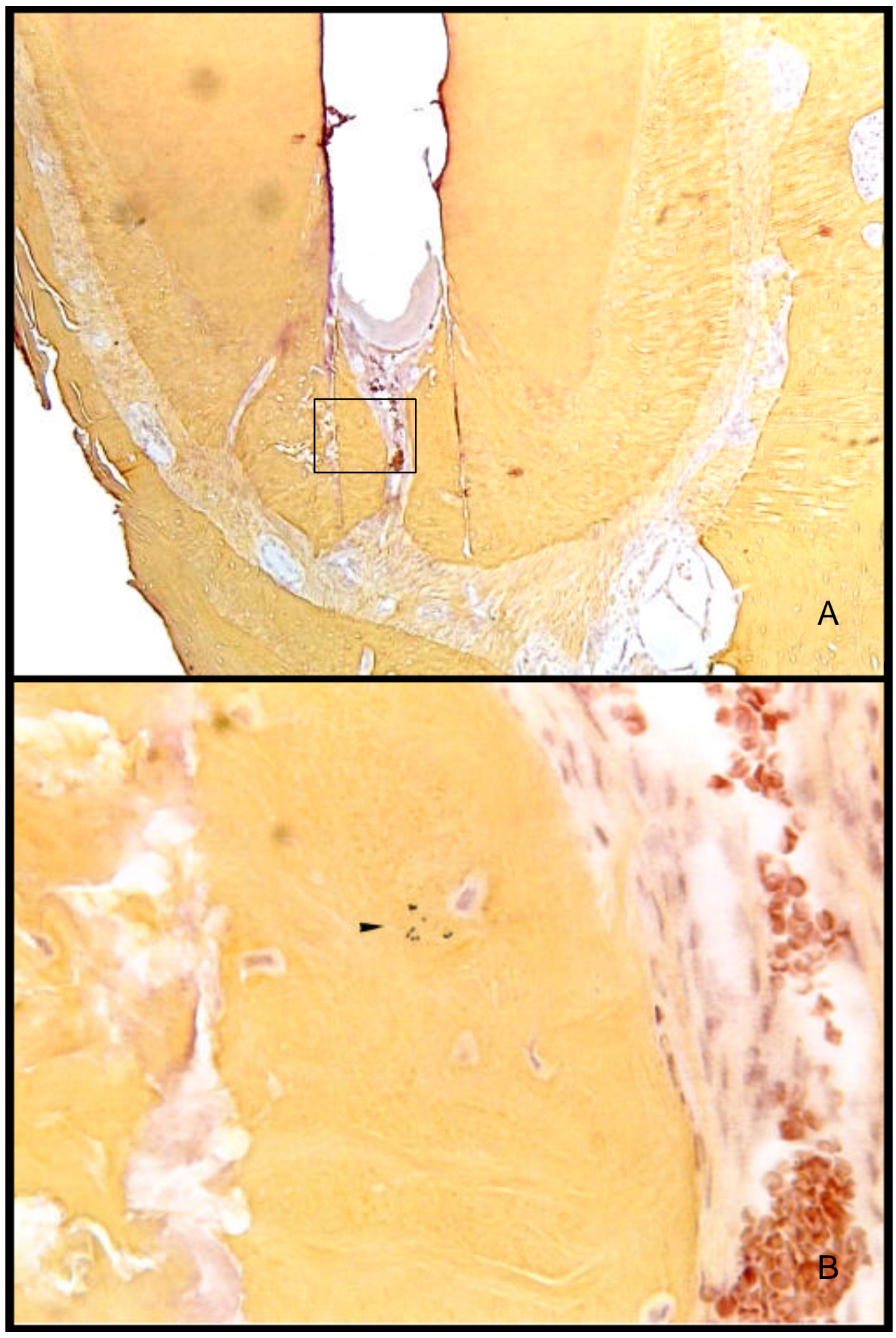

FIGURA 5 - A) Terço apical de dente com obturação nível 1 do período de 48h após a bacteremia. Verifica-se deposição lateral de cemento na parede interna do canal cementário e normalidade do periodonto apical e lateral. B) Maior aumento evidenciando presença de cocos Gram + (seta) no cemento depositado (aumento original: $A=40 X$; $B=400 X$; Brown e Brenn) 


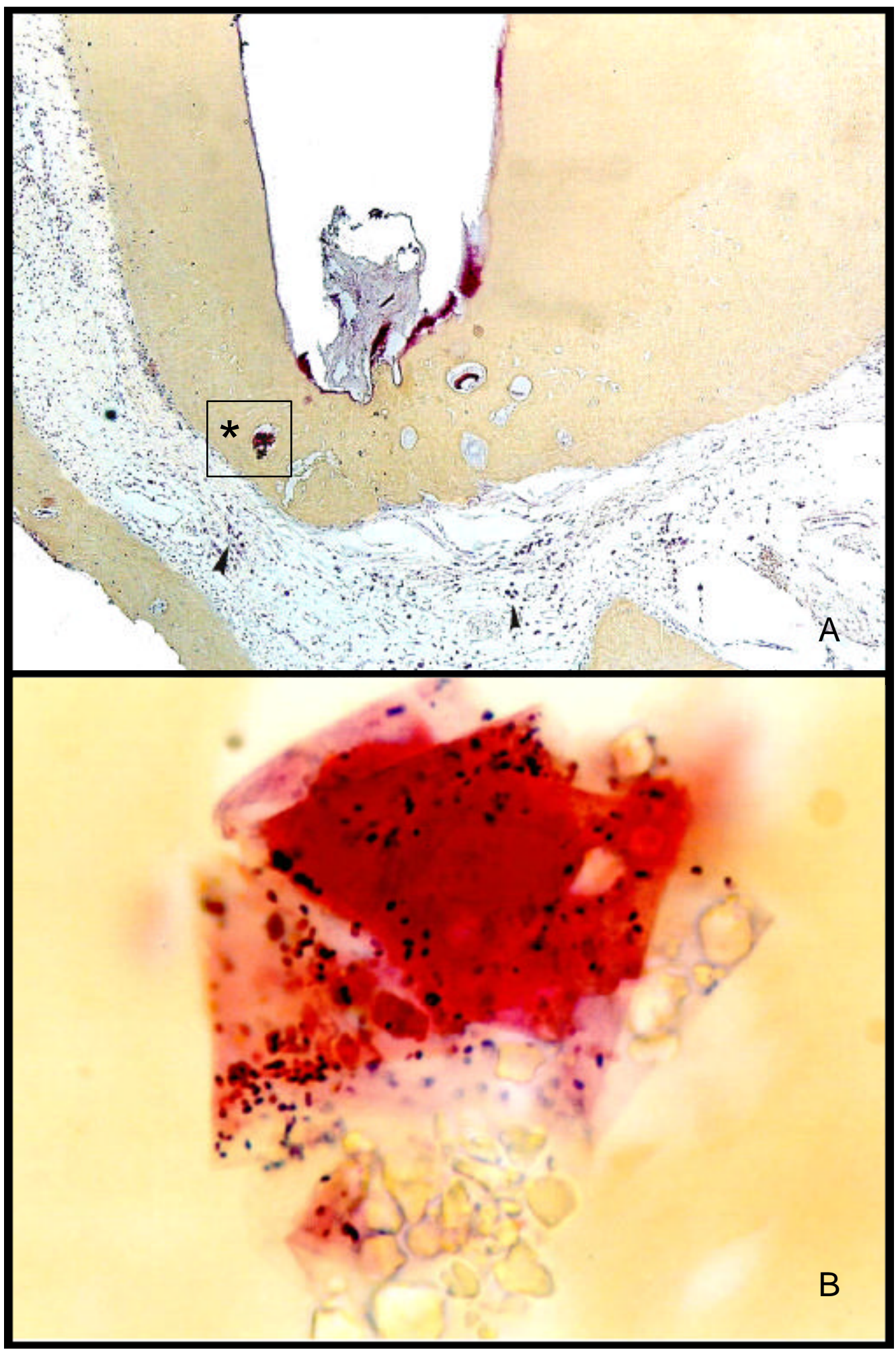

FIGURA 6 -A) Terço apical de dente com obturação nível 1. Nota-se presença de detrito na região de delta apical $\left({ }^{*}\right)$. No periodonto apical encontram-se macrófagos contendo Leishmania sp. (setas). B) Detritos com presença de cocos Gram + (aumento original: $A=40 X ; B=1000 X$; Brown e Brenn) 


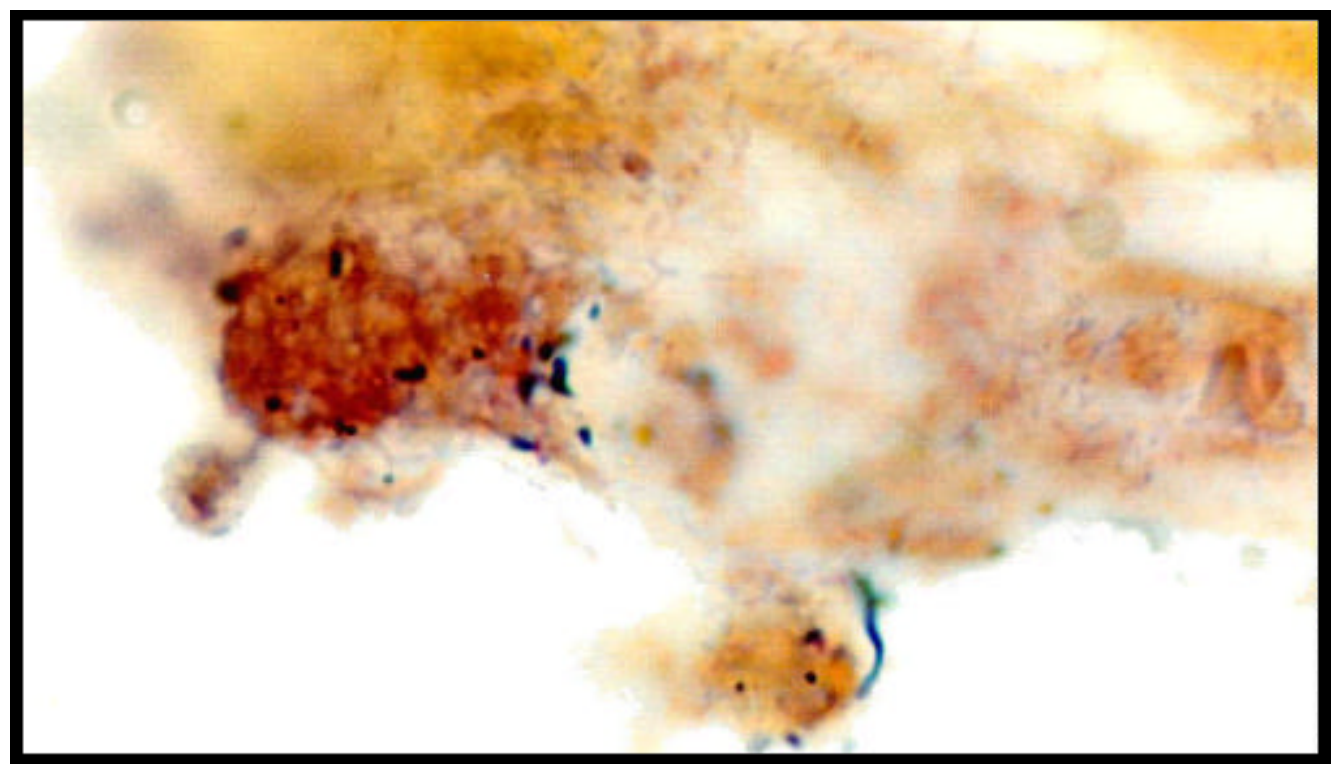

FIGURA 7 -Bactérias Gram + aderidas a detrito no canal cementário (aumento original: 1000X; Brown e Brenn)

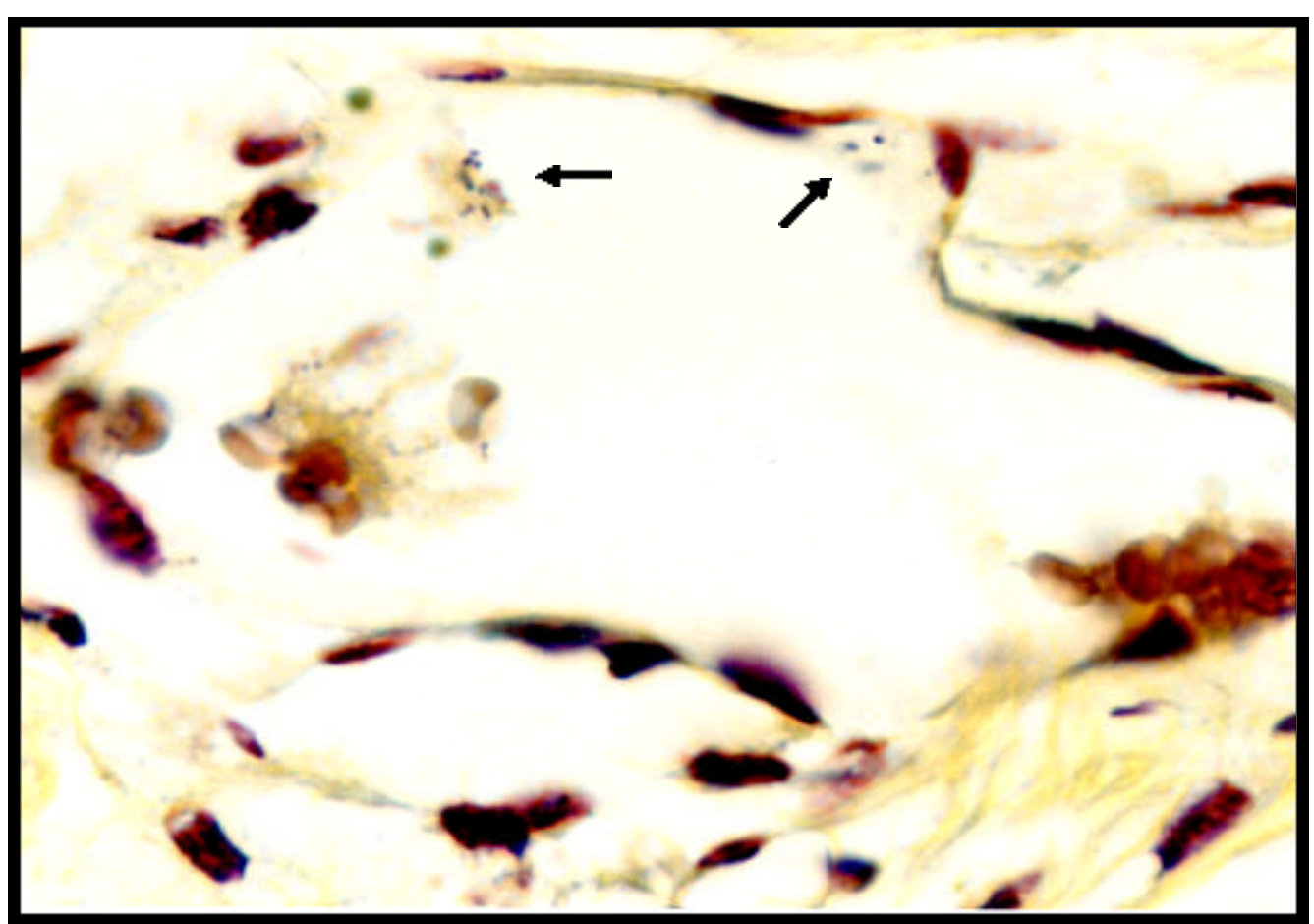

FIGURA 8 -Bactérias Gram + no interior de células dentro de um vaso sangüíneo e na sua parede, 48h após a bacteremia (aumento original: 1000X; Brown e Brenn) 


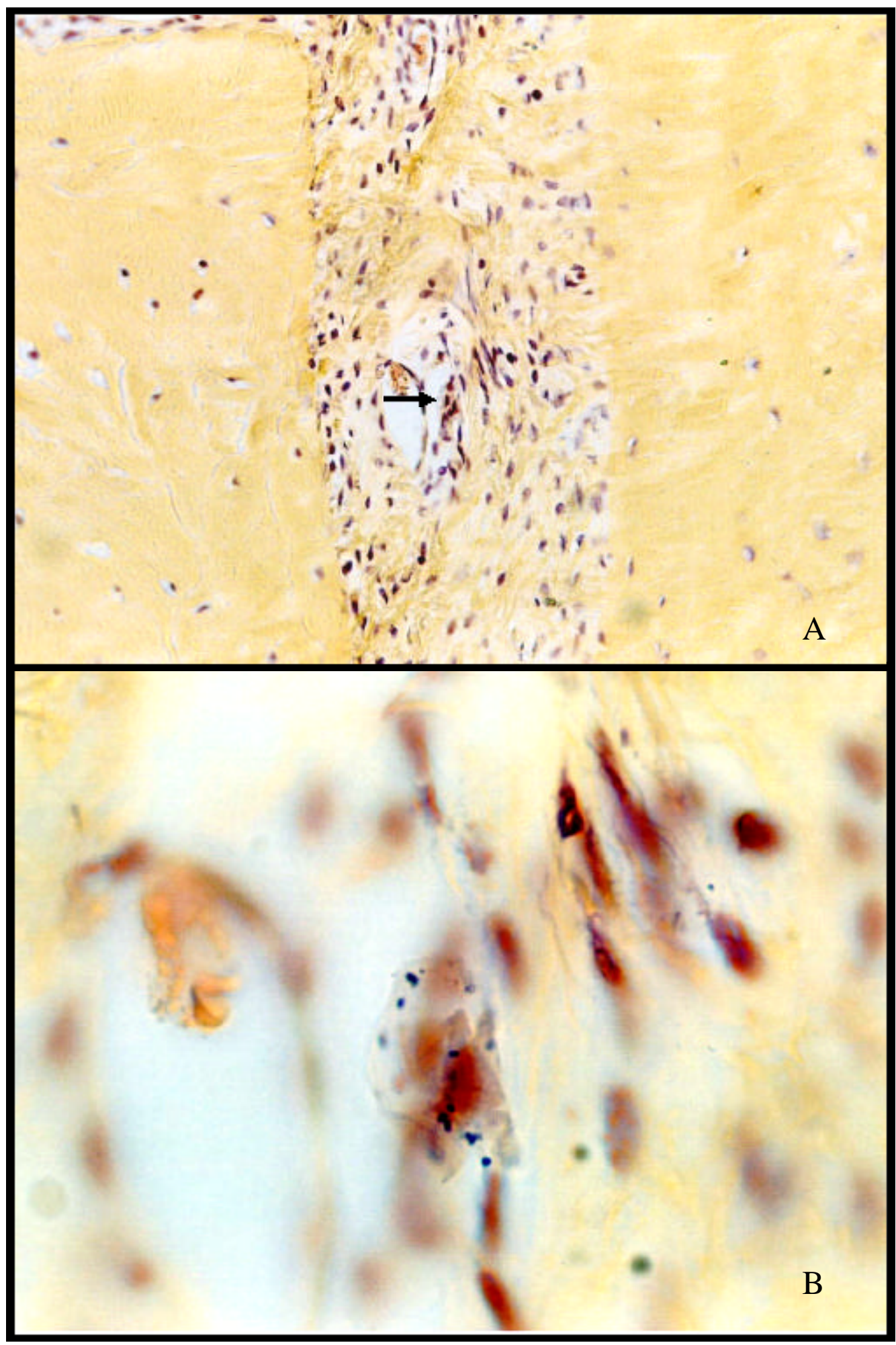

FIGURA 9 -A) Periodonto lateral. Nota-se a presença de célula fagocitária próximo a um vaso (seta). Do lado esquerdo osso, do lado direito cemento. B) Em maior aumento, macrófago com cocos Gram + no seu citoplasma (aumento original: $A=200 X ; B=$ 1000X; Brown e Brenn) 


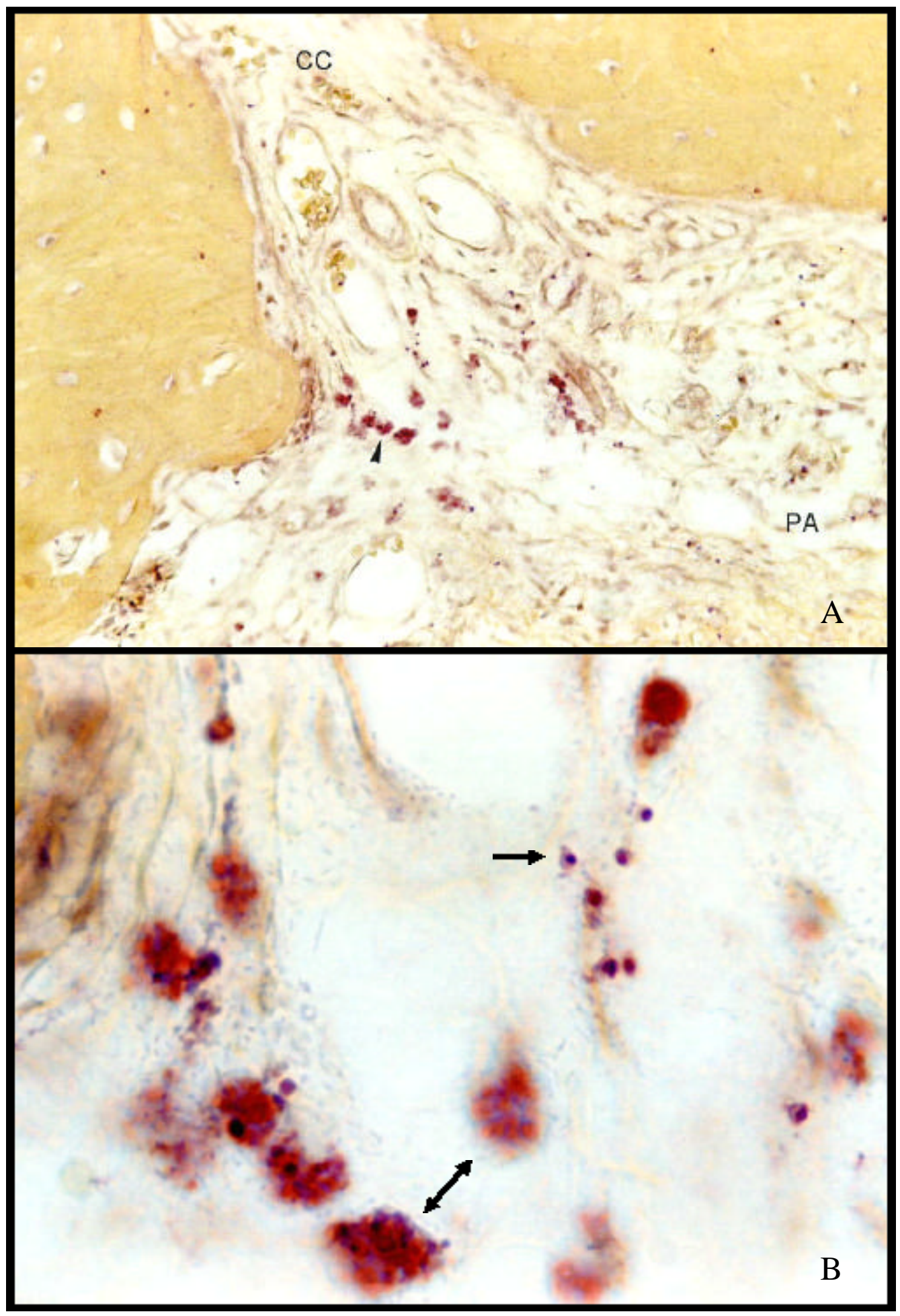

FIGURA 10 - A Limite entre canal cementário (CC) e periodonto apical (PA) exibindo macrófagos com protozoários (seta). B) Em maior aumento percebe-se Leishmania sp. no citoplasma dos macrófagos e no tecido conjuntivo (aumento original: $A=$ 200X; B = 1000X; Brown e Brenn) 


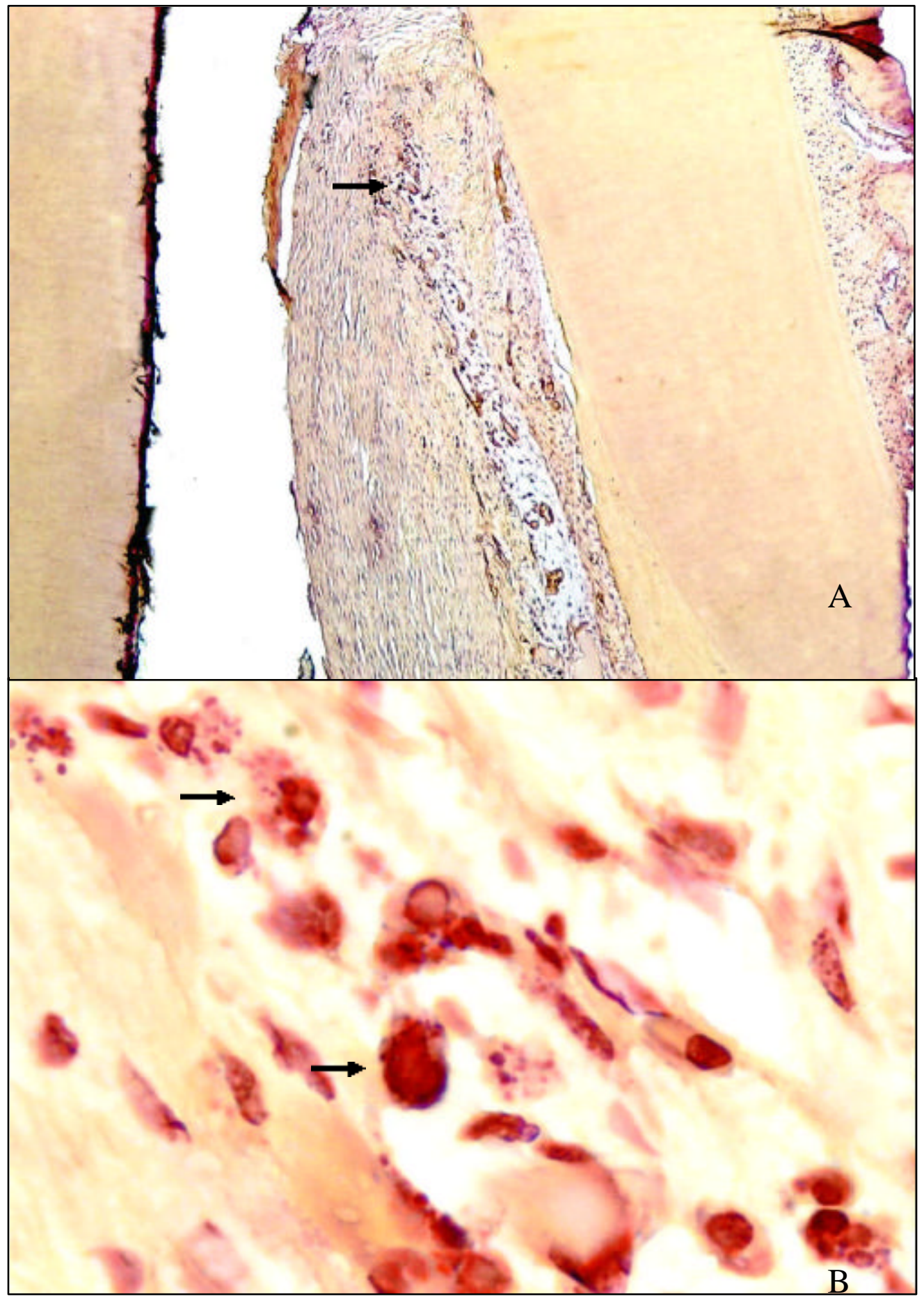

FIGURA 11 - A) Terço médio de canal com tecido conjuntivo periodontal invaginado. Pode-se observar presença de macrófagos com protozoários (seta). B) Maior aumento evidenciando macrófagos com Leishmania sp. no citoplasma (aumento original: $A=40 X ; B=1000 X$; Brown e Brenn) 
6 DISCUSSÃO 


\subsection{Da concepção}

Num passado não muito distante, a obturação do canal radicular só era autorizada mediante a obtenção de resultado negativo de cultura realizada. Quando ocorria crescimento bacteriano no meio de cultura o cirurgião-dentista iria reinstrumentar o canal e colocar novo curativo no intuito de obter a tão sonhada "esterilização" do canal.

Atualmente, basta abrirmos os jornais de associações de classe e nos deparamos com uma infinidade de propagandas sobre cursos de "como fazer endodontia em sessão única", principalmente nos casos de necrose pulpar, a despeito da contaminação existente no interior dos canais radiculares, suas adjacências e periodonto acometido por lesões periapicais ${ }^{51,52,56,58,60}$ e da superioridade do tratamento com a utilização de curativo de demora sobre a sessão única em necropulpectomias ${ }^{11,54}$.

A tendência para sempre se tratar qualquer caso clínico do mesmo modo e em sessão única, contribui acentuadamente para que o clínico não se preocupe mais em fazer diagnóstico conscientemente; isto implica em não exercitar a capacidade analítica clínica: Para que raciocinar se tudo é tratado da mesma forma?

A luta incessante pelo restabelecimento estético do paciente levou a dentística operatória ao aprimoramento de agentes de união cada vez mais eficazes, não só proporcionando embricamento mecânico ao esmalte, mas cada vez mais adesivos à dentina. Esta mesma dentina que a 10 anos estava totalmente intocada e protegida por materiais brradores, começou a ser alvo de condicionamento ácido. Inicialmente apenas em cavidades mais rasas, logo chegando a casos onde ocorriam exposições pulpares. Sendo, na seqüência, preconizada a hibridização do complexo dentino-pulpar. O que teria ocorrido $\infty \mathrm{m}$ a fisiologia pulpar, se este tecido 
teria deixado de ser em poucos anos extremamente frágil e se tornado extremamente resistente?

A grande mudança da Odontologia moderna arrebanha grande número de adeptos e logo vieram publicações comprovando a veracidade dos tratamentos realizados, baseados na experiência clínica e ausência de sintomatologia pós-operatória imediata, sem estudos metodologicamente embasados e interpretados.

A endodontia atual, visto o ocorrido com a dentística restauradora, está passando por uma fase tecnicista onde o dentista valoriza mais o "como fazer" do que o "porquê fazer". Inúmeras técnicas modernas de preparo biomecânico surgiram com novas ligas metálicas que proporcionam instrumentação com rotação de 360ำ no interior do canal, instrumentos movidos a motor de baixa velocidade controlada.

O tecido periodontal apical que outrora era sagrado, devendo ser resguardado de quaisquer agressões durante os procedimentos endodônticos, teve sua importância deixada de lado para os adeptos ao tecnicismo, visto o ocorrido com a polpa.

A grande importância atual está para os trabalhos clínicos que confirmaram os procedimentos baseados na ausência de sintomatologia pós-operatória imediata, enquanto que trabalhos biológicos in vivo podem deixar de ser considerados tão importantes. Comercialmente, esta postura se faz atraente e conveniente.

Associados às novas técnicas de preparo, surgem inúmeras para obturação com a finalidade de simplificar ao máximo a execução deste procedimento. Não importando muito se o material vai ficar restrito ou não ao interior dos canais radiculares, porque muitos acreditam ser mais importante "o que se tira do que o que se põe no canal". Esta frase pode ser assim traduzida "pode-se até levar à inflamação, degeneração e necrose ao redor do material ou produto colocado em contato ou no interior do tecido, desde 
que não promova sintomatologia ou problemas clínicos relativamente endodônticos nos curtos períodos pós-operatórios".

A maioria das escolas de endodontia ainda preconiza que a obturação dos canais seja realizada aquém do forame apical e o tecido periodontal apical respeitado. Algumas vezes, contudo, ocorre a sobreobturação. Tal fato nos levou a analisar a ocorrência da anacorese experimentalmente tanto em canais obturados aquém do forame apical, quanto nos portadores de sobreobturação. O limite da obturação é fator relevante no resultado do tratamento endodôntico; canais obturados aquém do forame apical apresentam melhores resultados que casos com sobreobturação ${ }^{36,63}$.

Ainda na concepção do trabalho, preocupourse com 0 comprometimento dos animais pela leishmaniose em função da epidemia registrada em Araçatuba, com o sacrifício de milhares de cães.

Os testes prévios foram providenciados e negativados, mas uma abordagem foi originariamente feita: não poderíamos usar como microrganismo teste, para ocorrência de anacorese, o protozoário Leishmania sp.? Dois fatores levaram-nos a decidir por assim não considerálo:

- tamanho muito maior que as bactérias o que provavelmente dificultaria sua saída vascular e;

- a falta de sequer uma menção na literatura da qual pudéssemos nos orientar.

Desta forma optou-se por considerar a presença do parasita um achado coincidental se fosse visualizado, como ocorreu. 


\subsection{Da metodologia}

\subsubsection{Do tratamento endodôntico}

Todos os procedimentos empregados durante a fase endodôntica do experimento são rotineiramente utilizados nos trabalhos experimentais em cães realizados na Disciplina de Endodontia da Faculdade de Odontologia de Araçatuba - UNESP e padronizados a partir de numerosos trabalhos publicados desde $1964^{37,39,80}$.

Durante toda a fase de preparo biomecânico foi utilizada a solução de Milton $(\mathrm{NaOCl}$ 1\%), para irrigação. Todo o tratamento endodôntico foi realizado sob isolamento do campo operatório com lençol de borracha para se evitar a contaminação dos canais radiculares. Pudemos constatar a eficácia da metodologia neste sentido visto que bactérias não foram observadas nas paredes dentinárias dos canais.

Dentes de cães terminam em um delta apical, o que favorece a determinação do comprimento de trabalho e preparo biomecânico. Com a finalidade de tornar sua porção apical anatomicamente mais semelhante a dos dentes humanos foi realizada sobre-instrumentação, "criando" uma terminação do canal principal com forame mais amplo que os forames das ramificações do delta apical.

Os vários níveis de obturação foram considerados devido às diferentes respostas do organismo frente aos mesmos. Obturações de canais contidas no seu interior, ou seja, aquém do foram apical apresentam melhores resultados biológicos que casos de sobreobturações ${ }^{36^{*} \star}$. Associado ao nível de obturação, vem a proporção pó/líquido do cimento empregado, pois o poder irritante está diretamente relacionado à concentração de líquido na pasta ${ }^{35}$. BERNABÉ ${ }^{7}$ encontrou selamento biológico após tratamento endodôntico via retrógrada em casos obturados com OZE consistente $1 \mathrm{~mm}$ aquém do nível de apicectomia, enquanto que na consistência de cimento

\footnotetext{
* HOLLAND,R. Faculdade de Odontologia de Araçatuba, UNESP) comunicação pessoal. 2001.
} 
endodôntico, em contato com tecido conjuntivo, provoca acentuada irritação tecidual ${ }^{35}$. SOARES et al. ${ }^{69}$ não observaram diferença de resultado frente a obturações com diferentes concentrações de eugenol no cimento OZE quando as obturações foram realizadas $1 \mathrm{~mm}$ aquém do forame apical.

O óxido de zinco e eugenol é componente base da maioria dos cimentos endodônticos. BERNABÉ ${ }^{7}$ realizou extensa revisão sobre este material e seus componentes, realçando o maior potencial agressivo aos tecidos ser característica do eugenol, variando conforme sua concentração ${ }^{47}$, sendo capaz de destruir células de mamíferos e inibir o metabolismo bacteriano em concentrações acima de $10^{-2} \mathrm{Mol} / \mathrm{L}^{43}$.

A liberação de eugenol da massa 0 cimento ocorre em maior quantidade nos períodos iniciais ${ }^{7,43}$. ABOU-HASHIEH et al. ${ }^{1}$ avaliaram a concentração de eugenol liberado após obturações de canais realizadas aquém do forame apical, verificando que a liberação inicialmente era mais elevada e aos 30 dias não mais era detectada. HUME $^{42}$ (1983) removendo mecanicamente amostras de $1 \mathrm{~mm}$ de espessura do cimento OZE, que estavam sendo observadas há 33 dias, recolocando estes pequenos fragmentos em meio aquoso observou liberação de eugenol nos mesmos níveis daquele observado nos períodos iniciais. A diminuição da liberação de eugenol com o tempo provavelmente se relaciona com a grande distância percorrida durante a difusão da água para dentro da massa do cimento e na saída do eugenol ${ }^{42}$. A despeito dessa controvérsia, SELTZER ${ }^{63}$, realizou apicectomia em 14 raízes obturadas com cimento de óxido de zinco e eugenol nos períodos de 12, 18 e 30 meses após o tratamento endodôntico, observando sobreobturação e reação inflamatória em contato com o material obturador.

Independentemente do tratamento efetuado, BRYNOLF ${ }^{15}$ revelou que apenas $7 \%$ dos casos endodonticamente tratados podem ser considerados microscopicamente bem sucedidos. Entende-se por microscopicamente bem sucedido, os casos em que os tecidos recuperaram, por completo, a organização normal, sem qualquer infiltrado celular ou plasmático de natureza inflamatória. 


\subsubsection{Emprego de microrganismo com marcador}

O emprego de microrganismos com marcadores de resistência a antimicrobianos em estudos de virulência ou ecológicos em modelos animais é útil em microbiologia ${ }^{40}$. Em estudos sobre adesão microbiana in vitro, infecção experimental e anacorese constitui metodologia estabelecida $^{18,24,25}$, tendo sido utilizada nos últimos 60 anos.

A utilização de microrganismos resistentes em estudos similares ao atual deve procurar respeitar algumas condições a saber. Primeiramente, é desejável que o microrganismo possua marcadores múltiplos de resistência para individualizá-lo dos demais que coabitam no mesmo sítio anatômico, o que neste estudo não constituiu problema, uma vez que o preparo biomecânico e a obturação do sistema de canais radiculares foi realizada em casos de biopulpectomia e de acordo com os princípios de assepsia. Também marcadores de resistência devem, preferencialmente, não ser observados com freqüência em outras cepas da espécie a ser utilizada, o que vem se tornando difícil de ser obtido, em função da disseminação do uso abusivo de antimicrobianos e conseqüente seleção de bactérias resistentes.

A possibilidade de que isolados de $S$. pyogenes integrantes da microbiota normal ou suplementar dos cães utilizados no estudo tenham desenvolvido, através de aquisição de genes ou mutação aleatória, o mesmo perfil de susceptibilidade da cepa teste inoculada é extremamente remota, desde que esta última apresenta resistência múltipla.

Para minimizar esta possibilidade, determinaram-se as concentrações inibitórias mínimas (CIM) de diferentes drogas para a cepa teste antes da inoculação no modelo animal e após a recuperação da mesma (Tabela 1), de forma que não apenas se verificou a resistência ou susceptibilidade em termos qualitativos, mas também em termos quantitativos o que praticamente elimina a possibilidade aventada acima. 
As pequenas diferenças quanto à CIM dos antimicrobianos para o microrganismo inoculado quando comparadas com os mesmos valores para o microrganismo recuperado são insignificantes e estão dentro das variações inerentes à metodologia utilizada ${ }^{22}$.

A inoculação desses microrganismos nos animais experimentais tem sido realizada pela via intraperitonial ${ }^{2,14,46,76}$ que posteriormente atinge a corrente sangüínea, ou diretamente por injeção venosa ${ }^{8,16,18,19,20,25,59,74}$ como no caso do presente experimento.

\subsubsection{Processamento laboratorial das peças para microscopia}

Vários trabalhos vem utilizando o método de coloração de Brown e Brenn, introduzido à técnica microscópica em 1931 11,12,54,56,58.

O efeito cumulativo sobre os tecidos, pelos agentes químicos empregados na desinfecção, fixação, desmineralização e inclusão em parafina, faz com que parte das bactérias sejam eliminadas ou percam a capacidade tintorial pela técnica de Brown e Brenn ${ }^{78}$ podendo levar a falsas interpretações dos cortes em tecidos e influenciar no resultado de uma pesquisa.

Os resultados obtidos pelo emprego do EDTA, no presente experimento, foram considerados satisfatórios preservando o arcabouço estrutural dos tecidos na grande maioria dos cortes analisados, onde puderam ser evidenciadas bactérias.

Embora esta metodologia não seja a ideal, pois de acordo com trabalho de WIJNBERGEN; VAN MULLEM ${ }^{77}$ (1987), substâncias químicas utilizadas na desmineralização de tecidos, testadas e empregadas em seu experimento, contribuíram para a perda da afinidade tintorial de bactérias Gram positivas. As alterações mais significativas foram observadas com ácido fórmico a 5\%, empregado por uma semana. A cada 15 bactérias, somente uma corou de azul, porém com EDTA a redução foi menor, corou 1 
a cada 3. Portanto, em áreas com limitado número de bactérias, como é o caso do presente trabalho, o risco de resultados falsos negativos torna-se bastante significativo ${ }^{77}$. Isto nos leva a concluir que grande parte das bactérias contidas nos espécimes por nós estudados, possivelmente não tenha sido detectada.

TZIAFAS, em 2001*, acredita particularmente, que o uso da histobacteriologia tem vantagens e desvantagens. Enquanto é possível localizar as bactérias nos cortes, sua identidade não pode ser determinada a menos que métodos de cultura sejam empregados. Obviamente é coerente assumir que as bactérias vistas nos cortes são as mesmas injetadas, mas prova irrefutável requereria o uso de bactérias marcadas que poderiam ser recuperada deste tecido, tal qual realizado no presente trabalho.

\subsection{Dos Resultados}

\subsubsection{Implantação de microrganismo exógenos}

A implantação de microrganismos exógenos na boca é dificultada pela competição com a microbiota bucal, componentes da saliva e outros mecanismos de defesa do hospedeiro e somente se processa quando se cria uma "fenda" nesse esquema ${ }^{61}$, dependendo, por vezes, da supressão da própria microbiota indígena, que poderia vir a competir com o "intruso" por espaço e/ou nutrientes ${ }^{29}$.

No presente experimento não se observou a necessidade de realizar a antibioticoterapia prévia, uma vez que o microrganismo a ser inoculado por via endovenosa não deveria sofrer efeitos de concorrência com a microbiota bucal.

*TZIAFAS,D. Comunicação pessoal, via e-mail (Anexo3). 
Por outro lado, sabe-se de numerosas interações sinergísticas entre espécies microbianas na cavidade bucal e em outros habitats. Dessa forma, a inexistência de uma microbiota endodôntica típica pode ter dificultado o estabelecimento do microrganismo inoculado, o que criaria uma monoinfecção.

Outro aspecto que merece considerações está na sensibilidade da cultura e histobacteriologia para a detecção de microrganismos em amostras clínicas. A cepa de Streptococcus pyogenes utilizada nos testes foi isolada de amigdalite e pode não ter produzido uma infecção significativa na região periapical de alguns dentes tratados, não tendo atingido o limiar de detecção do método, o qual não está bem estabelecido para endodontia. As condições ambientais presentes na região periapical podem não ter se mostrado favoráveis à proliferação e a recuperação microbiana dificultada pela manipulação dos espécimes no laboratório.

A adesão microbiana aos tecidos periapicais pode ter dificultado o isolamento bacteriano, mesmo após a maceração do periápice dentário e emprego do vórtex (agitador de tubos) para a dispersão bacteriana. Nesse sentido, poder-se-ia, em estudos futuros, empregar agentes, como o Tween 80, capazes de diminuir a hidrofobicidade bacteriana $\mathrm{e}$, por conseguinte, a adesão ao hospedeiro, facilitando 0 isolamento do microrganismo alvo. Contudo em função da manipulação das peças teciduais durante a remoção, transporte e maceração da mesma, optou-se por não utilizar compostos tensoativos que também podem reduzir a viabilidade de algumas células microbianas ${ }^{9}$.

Em estudos futuros dessa natureza, pode-se procurar realizar procedimentos de pré-enriquecimento na tentativa de obter uma maior freqüência de recuperação de microrganismo testado, o que é amplamente utilizado em microbiologia médica e ambiental. 


\subsubsection{Microrganismos diferentes que apareceram nos espécimes de 30 dias após bacteremia}

A presença de outros grupos microbianos nos animais sacrificados após 30 dias pode não apenas significar contaminação durante a remoção as peças, mas também a disseminação de microrganismo bucais e intestinais para a região periapical a partir de quadros bacterêmicos e anacorese. Nesse particular ALLARD et al. ${ }^{4}$ sugerem a possibilidade acima aventada.

\subsubsection{Os porquês de não aparecer os microrganismos}

LUZ CENTELES et al. ${ }^{75}$ comenta que formas crônicas de osteomielites têm sido objeto de estudo bacteriológico, mas na maior parte das amostras não se têm encontrado bactérias. Não que estas não estejam presentes no tecido ósseo, aparecem com pouca densidade e são difíceis de detectar em amostras bacteriológicas. Ou ainda por que se encontram organizados nas superfícies ósseas internas e nas irregularidades próprias da estrutura óssea como lacunas de Howship e cementoplastos ${ }^{57}$.

Os componentes do soro humano com atividade antimicrobiana podem exercer notável pressão seletiva sobre a microbiota normal, impedindo ou dificultando a disseminação de patógenos ${ }^{73}$. Alguns microrganismos desenvolveram estratégias que permitem a evasão do sistema de defesa presente no soro, principalmente por meio de proteases capazes de degradar componentes do sistema complemento e imunoglobulinas ${ }^{23,53,70,71,73}$. Uma forma de organização bacteriana que visa sua proteção de fatores da defesa orgânica e medicamentos são os biofilmes microbianos ${ }^{56,57,58}$.

A ativação do sistema complemento pela via clássica ou alternativa, levando à liberação de fatores quimiotáticos para leucócitos, aminas vasoativas, anafilotoxinas e produzindo danos à parede celular 
bacteriana pode constituir elemento de relevância no desenvolvimento e evolução das periapicopatias.

De acordo com BRAMANTI et al. $^{13}$ microrganismos patogênicos, durante o desenvolvimento de quadros infecciosos estão sujeitos a intenso estresse ambiental/tecidual, sendo que a expressão da virulência bacteriana responsável pela colonização de novos ambientes, danos ao hospedeiro e evasão das defesas deste último ${ }^{67}$, está intimamente associada a esses fatores ambientais.

Desta forma, a ausência de recuperação do microrganismo teste nos animais sacrificados após 30 dias da inoculação experimental não significa, necessariamente que este não estava presente, mas talvez, a somatória do estresse representado pelos fatores relativos ao hospedeiro, tenham se somado aos efeitos deletérios do processamento laboratorial e para exérese e transporte da peça tecidual. Nesse ínterim, cabe ressaltar a importância de metodologias que não dependem da viabilidade microbiana, como PCR (Polymerase Chain Reaction), as quais poderiam ter sido utilizadas.

Embora o uso do PCR para a detecção de marcadores genéticos do microrganismo teste, represente excelente recurso em função da elevada sensibilidade e especificidade, não se pode deixar de considerar suas limitações. A necessidade de infra-estrutura específica e com requerimentos especiais para se evitar a contaminação das peças e do sistema de ampliação com DNA, e também, a disponibilidade de primers específicos para o microrganismo testado, uma vez que várias espécies microbianas podem possuir esses marcadores.

A separação de cepas diferentes mas da mesma espécie necessita de conhecimentos genéticos mais detalhados do microrganismo alvo e de outros membros de $S$. pyogenes, de forma que preferiu-se uma comparação entre os perfis de susceptibilidade a antimicrobianos e das características bioquímico-fisiológicas dos isolados o que constitui metodologia clássica. 
Os tecidos, inclusive pulpar e periapical, podem representar santuários de microrganismo que estejam passando naquele momento da coleta daquele tecido pela circulação local como demonstraram ABOUDHARAM et al. $^{2}$ e DRANCOURT et al. ${ }^{21}$. O PCR pode amplificar o DNA presente na área de passagem.

\subsubsection{Dos achados microscópicos}

Os resultados morfológicos observados com relação ao cimento obturador utilizado, OZE, estão de acordo com a literatura pertinente $^{32,33,34,35,36,63,69}$ e não constituem prioridade nas observações deste trabalho.

A inobservância de bactérias no interior dos canais radiculares era um fato previsível junto às paredes do canal e túbulos dentinários, visto que, todos os canais tratados eram casos de biopulpectomia e as condições de anti-sepsia foram mantidas durante todos os procedimentos endodônticos. A contaminação das paredes dentinárias e túbulos é muito comum em casos de necrose pulpar cuja origem bacteriana é coronária ${ }^{51,52,56,58}$.

No presente experimento a bacteremia ocorreu após a obturação dos canais, o que não justificaria a contaminação dos mesmos. Estes resultados encontram respaldo nos apresentados por DELIVANIS; FAN $^{19}$ e DELIVANIS et al. ${ }^{20}$ que deixando canais de dentes de gatos instrumentados e não obturados e submetendo os animais a bacteremia experimental, não observaram contaminação dos canais nos períodos de $48 \mathrm{~h}^{20}$ até 2 meses $^{19}$ e também nos achados de MÖLLER et al. ${ }^{50}$ que mantiveram canais de dentes de macacos necrosados, assepticamente selados por 6 meses não encontrando contaminação nos mesmos.

O fato de se colocar bactérias na circulação não significa necessariamente desenvolvimento de infecção, visto que mesmo a endocardite séptica normalmente acomete o endocárdio já lesado 
previamente por doença reumática, alterações valvulares (arteriosclerose, sífilis das semilunares aórticas) e má formação cardiovascular, por estarem submetidos a traumatismo anormal pela onda sangüínea, e também em áreas de microtraumatismos ${ }^{10}$.

As bactérias na corrente sangüínea sofrem ação de mecanismos de defesa tanto inespecíficos como específicos e apesar de seu reduzido tamanho de aproximadamente $1 \mu \mathrm{m}$ não são pequenas 0 suficiente para atravessarem vasos normais cujas fenestrações são muito reduzidas. Em locais onde haja aumento da permeabilidade vascular, por exemplo inflamação, a passagem das bactérias do interior dos vasos para o tecido conjuntivo é facilitada. Mesmo agora no tecido conjuntivo, para sobreviver, têm que encontrar sítios adequados para sua proliferação, preferencialmente locais onde o organismo não as possa combater, pois não estão organizadas e agrupadas em biofilme microbiano.

Apesar disso, microscopicamente foram observadas bactérias em $46,88 \%$ dos espécimes analisados após $48 \mathrm{~h}$ da bacteremia e em $28,12 \%$ após 30 dias. Grande parte destas bactérias no interior do citoplasma de células fagocitárias, o que não significa que estejam perdendo a viabilidade celular em função da fagocitose, visto que numerosos microrganismos podem até se multiplicar no interior de fagócitos ${ }^{62}$.

Embora haja relatos de culturas negativas de sangue após 20 minutos da bacteremia experimental em cães ${ }^{64}$ e após 30 minutos em camundongos $^{30}$ pudemos visualizar bactérias no interior de vasos após $48 \mathrm{~h}$ da inoculação. Provavelmente a diferença de resultados pode ter ocorrido devido a metodologia de análise ser diferente. Para cultura é necessário que as bactérias estejam presentes em número adequado, no local e momento da coleta sangüínea para a recuperação das mesmas. A visualização microscópica não nos autoriza comentar se estavam ou não viáveis, mas necessariamente se encontravam no local.

Algumas bactérias encontraram habitats propícios principalmente em áreas onde foram observados detritos oriundos do 
preparo biomecânico. Tal fator pode ser favorável ao seu desenvolvimento. ALLARD; STRÖMBERG ${ }^{3}$ consideram que 0 periápice de raízes pulpectomizadas e não contaminadas podem servir como área susceptível de contaminação (locus minoris resistentiae).

Desde 1957, McDONALD et al. ${ }^{48}$ acreditavam que a anacorese seria o provável responsável por $82 \%$ de casos de cultura positiva em dentes hígidos necrosados após traumatismos, pois as bactérias recuperadas dos canais eram representativas da microbiota bucal. Tal achado foi comprovado em 1962 por SMITH; TAPPE ${ }^{68}$ e em 1967 por GROSSMAN ${ }^{28}$.

GLICK et al., encontraram HIV em polpas ${ }^{26}$ e fibroblastos de polpa $^{27}$ não inflamadas, provavelmente levados pelo sangue. Mais recentemente, pela primeira vez, ABOUDHARAM et al. ${ }^{2}$ recuperaram, de polpas não inflamadas, de dentes de porquinhos da Índia, pelo método PCR, bactérias inoculadas intraperitonialmente, afirmando que se os resultados se confirmarem com outros patógenos a polpa dentária poderá ser considerada um santuário para a persistência de microrganismos.

Outro fator por nós avaliado foi o nível da obturação que sugere não ter influído no aparecimento das bactérias, quer no período de 48h, quer 30 dias, embora DELIVANIS; FAN ${ }^{19}$ só tenham observado culturas positivas de canais quando a sobre instrumentação foi realizada imediatamente após a bacteremia. Estes resultados parecem não apresentar muita correlação com os do presente trabalho, visto que a anacorese foi observada após 48h da bacteremia em canais obturados há 120 dias. Apesar da literatura relatar que nas fases iniciais de pós-operatório haja maior possibilidade de contaminação hematogênica ${ }^{8,16}$.

Esperávamos observar maior prevalência de bactérias quando o material obturador estivesse agredindo os tecidos periapicais (níveis 3 e 4 de obturação), devido à maior intensidade do processo inflamatório presente ${ }^{36}$, contudo verificamos que quando o periodonto apical estava mais 
saudável, nos casos de obturações do canal aquém do forame apical, a visualização das bactérias ocorreu em maior quantidade de casos.

Esses dados nos remetem a dois aspectos:

- o número de casos obturados no nível foi maior que os demais e isso pode ter alterado a real freqüência do fenômeno nos demais grupos;

- outro aspecto está em considerar os resultados e afirmar que mais importante, quanto à possibilidade da anacorese no ápice é a agressividade do material per si e não o nível de obturação.

A ocorrência da anacorese também pode ser verificada a partir dos dois animais com leishmaniose, mas com testes sorológicos inicialmente negativados. Em 11 periápices examinados nesses animais os parasitas estavam presentes. As leishmanias poderiam estar presentes em todo corpo? Provavelmente sim pois 4 raízes apresentaram-na no periodonto lateral. Esses resultados permitiram-nos inferir que a inflamação periapical acentuou sua saída do sangue para os tecidos. A presença inicialmente indesejada do ponto de vista metodológico acabou por enriquecer os resultados obtidos com as bactérias teste. A presença da leishmania nos animais não parece ter modificado os resultados, pois nos outros 2 animais as observações foram semelhantes.

Acreditamos que a maior desorganização do periodonto apical nos casos de grande extravasamento de material obturador, a dispersão de partículas do cimento utilizado, a propriedade bactericida do OZE, já discutida, associada à metodologia empregada no preparo das peças cirúrgicas $^{77,78}$ tenham dificultado ou até mesmo impedido a visualização das bactérias identificadas pela análise microbiológica.

Para este período de $48 \mathrm{~h}$ pós-bacteremia, podemos afirmar que as bactérias observadas sugerem, morfologicamente, ser as mesmas inoculadas, o que foi constatado pela cultura, evidenciando então, que o 
fenômeno de anacorese ocorreu, esses achados estão de acordo com o pensamento atual de TZIAFAS*.

A maior parte dos trabalhos relata anacorese com confirmação dos microrganismos utilizados em períodos pós-operatórios próximos ao da inoculação $8,16,25,59,74$. O presente experimento está em concordância a despeito das diferenças metodológicas empregadas.

Para o período de 30 dias pós-bacteremia, também foram observadas bactérias fagocitadas no periodonto lateral em 3 casos, provavelmente originadas de uma nova bacteremia natural a que os organismos estão sujeitos. Nesse período a maior parte dos microrganismos observados estava no canal cementário e delta apical, muitas vezes havendo sido englobados pela deposição de tecido duro reparatório. Pudemos assim verificar a capacidade de defesa do organismo que na maior parte dos casos conseguiu dar continuidade ao reparo a despeito da presença de microrganismos. Algumas vezes, quando as bactérias encontraram condições favoráveis para proliferação ocorreu o reparo do canal principal associado ao aparecimento de processo inflamatório junto a saída de canal do delta apical, caracterizando um processo ativo.

$\mathrm{Na}$ literatura estudada detectou-se a anacorese em polpas previamente inflamadas ${ }^{16,25,59,68}$ ou em processo de reparo ${ }^{74}$ com culturas de canais radiculares ${ }^{3,4,19}$. A área médica estuda-a em defeitos ósseos ${ }^{8}$, no endocárdio após manipulação bucal ${ }^{49}$ em endocardite experimental ${ }^{14,44}$, após hepatectomia ${ }^{76}$ e queimaduras experimentais ${ }^{46}$.

CSERNYEI $^{18}, 1939$, provocou lesões em periápice de dentes de cães deixando os canais vazios e expostos ao meio bucal, após algumas semanas e inoculou endovenosamente bactérias conhecidas. Após 3 semanas da bacteremia recuperou os microrganismos injetados dos periápices previamente inflamados.

${ }^{*}$ TZIAFAS,D. Comunicação pessoal, via e-mail (Anexo3). 
A diferença de resultado apresentada no presente trabalho no período de 30 dias com relação ao de CSERNYEI $^{18}$ provavelmente se relaciona à intensidade do processo inflamatório do primeiro trabalho onde os dentes foram deixados abertos e uma microbiota inespecífica já povoava a região periapical. No nosso experimento a inflamação do periápice foi muito menor, mesmo nos casos com maior extravasamento de material obturador e especialmente restritas a esses casos. Neste particular, GIER; MITCHELL ${ }^{25}$ 1968, ROBINSON; BOLING ${ }^{59}$, 1941, WANG et al. ${ }^{76}, 1992$, sugerem que inflamações mais acentuadas exercem maior poder anacorético.

Em suma, a ocorrência da anacorese vem explicar casos clínicos onde não haveria possibilidade de contaminação bacteriana da região pulpar ou periapical, mas mesmo assim com instalação de um processo inflamatório com sintomatologia pós-operatória significativa. Da mesma forma, a ocorrência da anacorese ajuda a compreender a etiopatogenia de casos com lesões periapicais crônicas em dentes sem doença periodontal, restaurações, fraturas e com história de traumatismo dentário. Nesses casos, o infarto pulpar pela ruptura do feixe vásculonervoso não seria suficiente para uma ampla lesão periapical crônica e muito menos justificaria surtos de agudescimento inclusive com formação de exsudato purulento.

A verificação da possibilidade de anacorese nos periápices dentários após tratamento endodôntico induz o repensar da frase na qual se diz "ser mais importante o que se remove ao que se aplica no canal radicular". A inflamação residual no periápice em função da capacidade irritativa do material por menor que seja também é importante, especialmente se em maior contato com os tecidos periodontais apicais como ocorre nos casos de obturação no limite ou sobreobturação.

A ocorrência de anacorese explica essas eventuais situações de lesões crônicas reagudescidas de forma considerada idiopáticas até em casos de biopulpectomias, mas deve-se ressaltar que esse fenômeno 
(anacorese) deve ser considerado eventual, pois esses problemas não são freqüentes na endodontia talvez porque a circulação sangüínea dos maxilares, em termos de volume de sangue por minuto, é pequena e muito menor ainda nas polpas dentárias cujo desenho propiciado pela distribuição dos vasos é arboriforme.

Finalmente pode-se questionar: se o fenômeno não é fato freqüente porque estudá-lo? Na clínica, os sucessos endodônticos fazem parte da rotina e das expectativas de todos; os insucessos inquietam e precisam ser evitados, mesmo que eventuais. 
7 CONCLUSÕES 


\section{CONCLUSÕES}

Fundamentados na literatura pregressa e em base dos resultados obtidos, mas considerando as limitações inerentes à metodologia, pudemos concluir que:

1 a anacorese ocorreu em periápice de dentes com canais obturados independentemente do nível de obturação;

2 as bactérias advindas da circulação podem implantar-se no periodonto apical e persistir, ou colaborar com o povoamento da região por outros patógenos mais adaptados;

3 a anacorese deve ser incluída como um dos fatores etiopatogênicos relativos às periapicopatias e no prognóstico e evolução do reparo periapical após o tratamento endodôntico. 
ANEXOS 
ANEXO 1 - Distribuição dos achados microscópicos quanto a presença, tipo e localização das bactérias e presença e localização de Leishmania sp. no período de 48h após bacteremia experimental

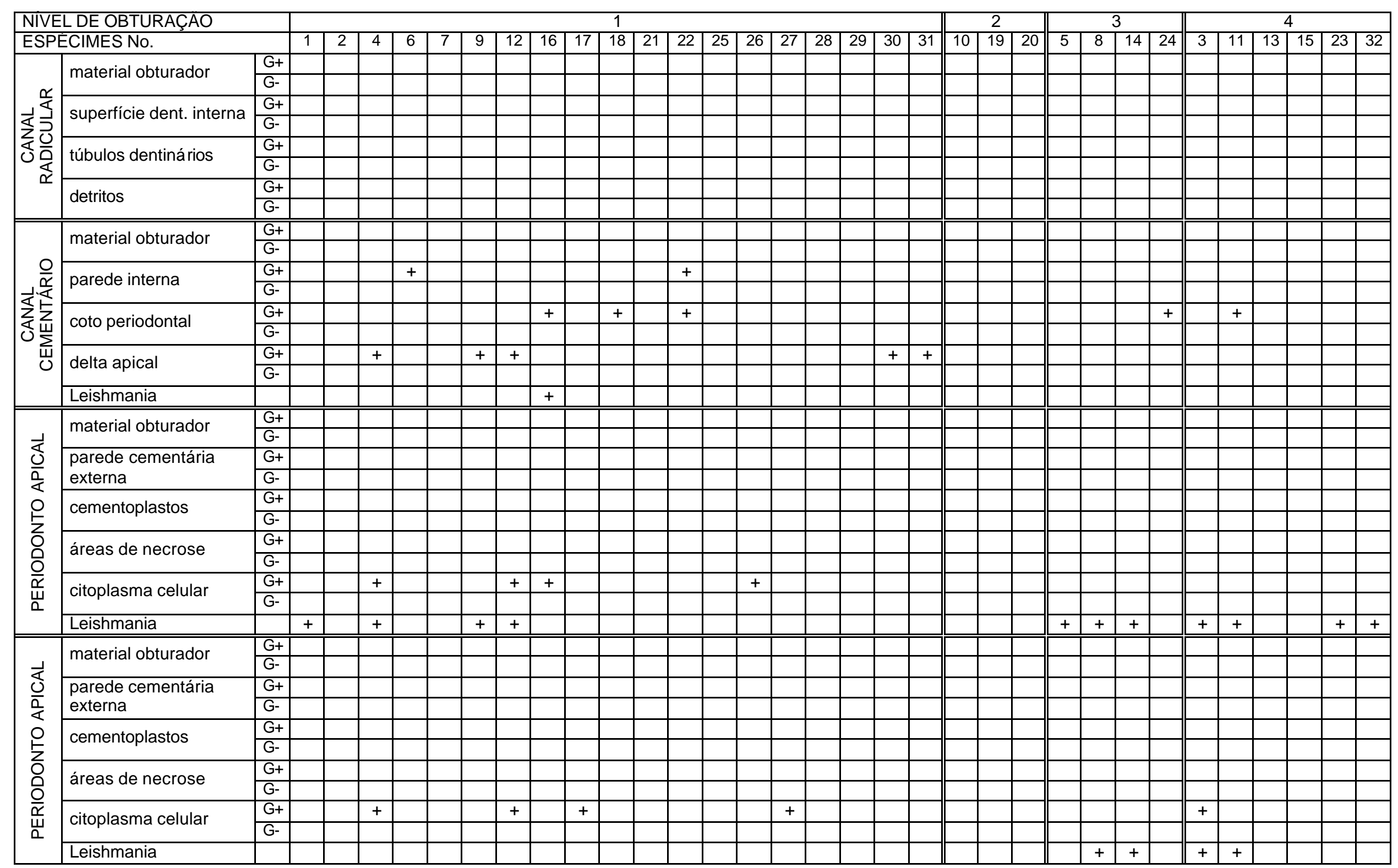


ANEXO 2 - Distribuição dos achados microscópicos quanto a presença, tipo e localização das bacté rias e presença e localização de Leishmania sp. no período de 30 dias após bacteremia experimental

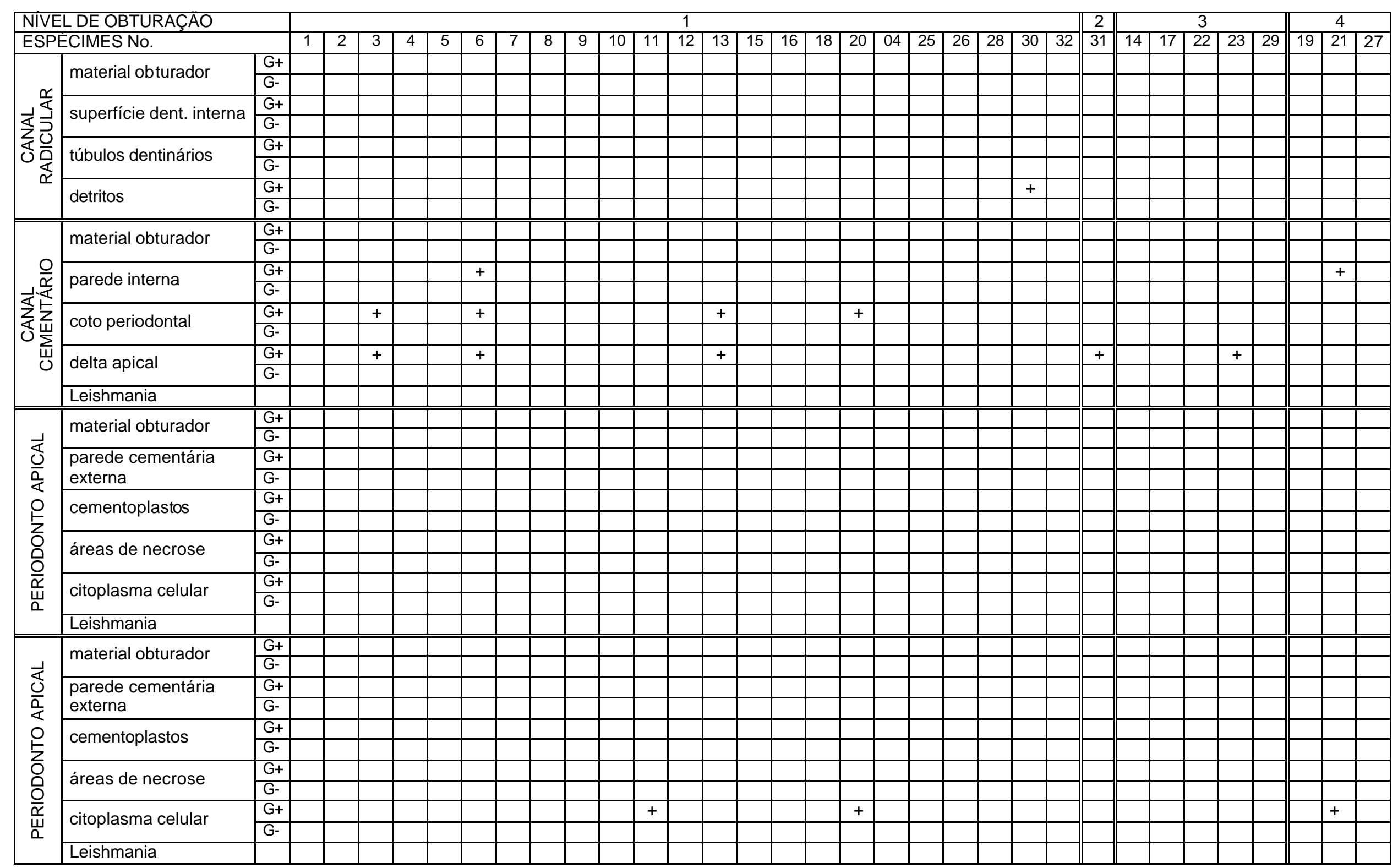




\section{ANEXO 3 Transcrição de e-mail recebido}

$\begin{array}{ll}\text { De: } & \text { Dimitrios Tziafas } \\ \text { Para: } & \text { Eloi Dezan Junior }\end{array}$

\section{Dear Eloi Dezan,}

Many tanks for your messages and interest on our work. I apologize for the delay in my reply but I was been away in France attending the last International Conference on Tooth Morphogenesis and Differentiation.

As it concerns to my previous work on anachoresis there were 2 papers. The first one in a Greek journal entitled "Experimentally induced pulpal anachoresis. A histologic study in dogs." focusing on the characteristics of anachoretic phenomenon in various stages of pulpal inflammation induced by exogenous thermal irritation. The second is that in Journal of Endodontics 1989. Then I stopped to work on this topic. I have been involved on projects related to reparative dentinogenesis and biodynamics of dentin regeneration from 1988 up to now.

Regarding my personal view (and as I remember it was the main criticism of the referees in above JE 1989 paper) about the research on anachoresis: as you know anachoresis is an ancient history; much classical research has proved its existence repeatedly over 40 years ago. Our studies confirmed the findings of previous investigations and generally did not add anything especially new to the already huge volume of research done on anachoresis. More particularly as it concerns to the methodology I consider that the use of histobacterial stains is such stadies has both advantages and disadvantages. While it is possible to localize bacteria in tissue sections the identity of the organisms cannot be determined unless culturing methods will bee employed. Of course it is reasonable to assume that bacteria seen in sections were the same as those injected, but absolute proof would require the use of labeled bacteria which could be recovered from the tissue. Another point is the correlation between the extent of hemorrhage and the presence of bacteria.

I am afraid that I am unable to give you more helpful comments on that topic. Of course I am at your disposal if I can do something for you.

All my kindest regards to Professor Roberto Holland.

All best

Dimitrios Tziafas 


\section{REFERÊNCIAS BIBLIOGRÁFICAS}




\section{REFERÊNCIAS BIBLIOGRÁFICAS*}

1. ABOU-HASHIEH,I.; POMMEL,L.; CAMPS,J. Concentration of eugenol apically released from zinc oxide-eugenol based sealers. J. Endod., v.25, n.11, p.713-5, Nov. 1999.

2. ABOUDHARAM,G.; LASCOLA,B.; RAOULT,D.; DRANCOURT,M. Detection of Coxiella burnetti DNA in dental pulp during experimental bacteremia. Microb. Pathog., v.28, n.4, p.249-54, Apr. 2000.

3. ALLARD,U.; STRÖMBERG,T. Inflammatory reaction in the apical area of pulpectomized and sterile root canals in dogs. Oral Surg., v.48, n.5, p. 463-6, Nov. 1979.

4. ALLARD,U.; NORD,C.E.; SJÖBERG,L.; STRÖMBERG,T. Experimental infections with Staphylococcus aureus, Streptococcus sanguis, Pseudomonas aeruginosa and Bacteroides fragilis in the jaws of dogs. Oral Surg., v.48, n.5, p.454-62, Nov. 1979.

5. ASCOLI,A. Pat. Comp. Tbc. v.2, p.191, 1938 apud CSERNYEI,J. ${ }^{18}$ p.527.

6. BAUNGARTNER,J.C.; HEGGERS,J.P.; HARRISON,J.W. Incidence of bacteremia related to endodontic procedures. II Surgical endodontics. J. Endod., v.3, n.10, p.399-402, Oct 1977.

7. BERNABÉ,P.F.E. Estudo histopatológico realizado em dentes de cães com lesão periapical após a apicectomia e tratamento endodôntico via retrógrada. Influência do nível da obturação e do material obturador. Araçatuba, 1994. 352 p. Tese (Livre Docência) - Faculdade de Odontologia de Araçatuba - UNIVERSIDADE ESTADUAL PAULISTA.

8. BLOMGREN,G.; LINDGREN,U. Postoperative infections resulting from bacteremia. An experimental study in rabbits. Acta Orthop. Scand., v.51, n.5, p.761-5, Oct. 1980.

9. BLOCK,S.S. Disinfection, sterilization and preservation. 4.ed. Philadelphia, Lea \& Febiger, 1991.

10. BOGLIOLO, L. Patologia. 5.ed. Rio de Janeiro; Guanabara Koogan, 1994.

\footnotetext{
*Normas recomendadas para uso no âmbito da Universidade de São Paulo, com base no documento "Referências Bibliográficas: exemplos", emanado do Conselho Superior do Sistema Integrado de Biblioteca da USP, em reunião de 20 de setembro de 1990.
} 
11. BONETTI FILHO,I. Tratamento de canal radicular de dentes de cães com necrose pulpar e lesão periapical crônica induzida, realizado em sessão única e duas sessões, utilizando três diferentes curativos de demora. Avaliação radiográfica e histomorfológica. Araraquara, 2000. 336 p. Tese (Livre Docência) - Faculdade de Odontologia de Araraquara - UNIVERSIDADE ESTADUAL PAULISTA.

12. BORRORQUEZ AVILA,S.P; ROCHA,R.S.S.; CONSOLARO,A. Avaliação da presença e localização de bactérias nos canais radiculares e nas lesões periapicais crônicas pelo método de coloração de Brown e Brenn. Rev. FOB, v.3, n.1/4, p.25-31, Jan./Dez. 1995.

13. BRAMANTI,T.E.; HOLT,S.C.; EBERSOLE,J.L.; VAN DYKE,T. Regulation of Porphyromonas gingivalis virulence: hemin limitation effects on the outer membrane protein (OMP) expression and biological activity. J. Periodont. Res., v.28, p.464-6, 1993.

14. BREITSCHWERDT,E.B.; GEOLY,F.J.; MEUTEN,D.J.; LEVINE,J.F.; HOWARD,P.; HEGARTY,B.C.; STAFFORD, L.C. Myocarditis in mice and Guinea pigs experimentally infected with a canine-origem Borrelia isolated from Florida. Am. J. Vet. Res., v.57, n.4, p.505-11, Apr. 1996.

15. BRYNOLF,I. A histological and roentgenological study of the periapical region of human upper incisor. Odont. Revy., v.18, 1967. Suppl.11.

16. BURKE,G.W.; KNIGHTON,H.T. The localization of microorganisms in inflamed dental pulps of rats following bacteremia. J. Dent. Res., v.39, n.2, p.205-14, Mar./Apr. 1960.

17. CARROLL,G.C.; SEBOR,R.J. Dental flossing and it's relationship to transient bacteremia. J. Periodontol., v.51, n.12, p.691-2, Dec. 1980.

18. CSERNYEI,J. Anacoric effect of chronic periapical inflammations. J. Dent Res., v.18, p.527-31, Dec. 1939.

19. DELIVANIS,P.D.; FAN,V.S.C. The localization of blood-borne bacteria in instrumented unfilled and overinstrumented canals. J. Endod., v.10, n.11, p.521-4, Nov. 1984.

20. DELIVANIS,P.D.; SNOWDEN,R.B.; DOYLE,R.J. Localization of bloodborne bacteria in instrumented unfilled root canals. Oral Surg., v.52, n.4, p.430-2, Oct 1981. 
21. DRANCOURT,M.; ABOUDHARAM,G.; SIGNOLI,M.; DUTOUR,O.; RAOULT,D. Detection of 400-year-old Yersinia pestis DNA in human dental pulp: an approach to the diagnosis of ancient septicemia. Proc. Natl. Acad. Sci. USA, v.95, n.51, p.12637-40, Oct. 1998.

22. FINEGOLD,S.M. Anaerobes: problems and controversies in bacteriology, infections and susceptibility testing. Rev. Infect. Dis., v.12, p.s223-30, 1990. Suppl. 2.

23. GAETTI JARDIM JR.,E.; AVILA CAMPOS,M.J. Antimicrobial effects of human serum on oral Fusobacterium nucleatum isolated from humans and monkeys. Rev. Odontol. USP, v.13, p.1-4, 1999.

24. GIBBONS,R.F.; VAN HOUTE,F. Selective bacterial adherence to oral epithelial surfaces and its role as an ecological determinant. Infect. Immun., v.3, p.567-73, 1971.

25. GIER,R.E.; MITCHELL,D.F. Anachoretic effect of pulpitis. J. Dent. Res., v.47, n.4, p.564-70, July/Aug. 1968.

26. GLICK,M.; TROPE,M.; PLISKIN,M.E. Detection of HIV in the dental pulp of patients with AIDS. J. Am. Dent Ass., v.119, n.5, p.649-50, Nov. 1989.

27. GLICK,M.; TROPE,M.; BAGASRA,O.; PLISKIN,M.E. Human immunodeficiency virus infection of fibroblasts of dental pulp in seropositive patients. Oral Surg., v.71, n.6, p.733-6, June 1991.

28. GROSSMAN,L.I Origin of microorganisms in traumatized pulpless sound teeth. J. Dent. Res., v.46, n.3, p.551-3, May/June 1967.

29. HAFFAJEE, A. D., SOCRANSKI, S. S. Microbial etiological agents of destructive periodontal disease. Periodontol. 2000, v.5, p.78-111, 1994.

30. HIRAKATA,Y.; KATU,M.; FURUYA,N.; MATSUMOTO,T.; TATEDA,K.; TOMONO,K.; YAMAGUCHI,K. Effect of clearance of bacteria from the blood on the development of systemic bacteremia in mice. $\mathbf{J}$. Med. Microbiol., v.38, n.5, p.337-44, May 1993.

31. HIRAKATA,Y.; FURUYA,N.; MATSUMOTO,T.; TATEDA,K.; YAMAGUCHI,K. Experimental endogenous septicaemia caused by Klebsiella pneumoniae and Escherichia coli in mice. J. Med. Microbiol., v.44, n.3, p.211-4, Mar. 1996.

32. HOLLAND,G.R. Neural changes in periapical lesions after systemic steroids in Ferret J. Dent. Res., v.72, n.6, p.987-93, June 1993. 
33. HOLLAND,G.R. A histological comparison of periapical inflammatory and neural responses to two endodontic sealers in the Ferret Arch. Oral Biol., v.39, n.7, p.539-44, 1994.

34. HOLLAND,G.R. Periapical neural responses to pulpectomy. In: SHIMONO,M et al. Dentin pulp complex: Proceedings of the International Conference on Dentin/Pulp Complex, 1995 and the International Meeting on Clinical Topics of Dentin/Pulp Complex. Tokyo Quintessence Publishing Company, 1996. p.274-5.

35. HOLLAND,R.; SOUZA,V.; HOLLAND JUNIOR.,C.; NERY,M.J. Estudo histológico do comportamento do tecido conjuntivo subcutâneo do rato ao implante de alguns materiais obturadores de canal radicular. Influência da proporção pó-líquido. Rev. Assoc. Paul. Odontol., v.25, n.3, p.101-10, maio/jun. 1971.

36. HOLLAND,R.; SOUZA,V.; NERY,M.J.; BERNABÉ, P.F.E. Comportamento do tecido conjuntivo subcutâneo de rato ao implante de tubos de polietileno preenchidos parcial ou totalmente com alguns materiais obturadores de canal. Rev. Bras. Odontol., v.28, n.171, p.197-201, set./out. 1971.

37. HOLLAND,R.; MELLO,W.; NERY,M.J.; BERNABÉ,P.F.E.; SOUZA,V. Reaction of human periapical tissue to pulp extirpation and immediate root canal filling with calcium hydroxide. J. Endod., v.3, p.63-67, 1977.

38. HOLLAND,R.; OTOBONI FILHO,J.A.; NERY,M.J.; BERNABÉ, P.F.E.; MELLO, W. Técnicas mistas de preparo do canal radicular. Rev. Paul. Odontol., v.13, p.17-23, 1991.

39. HOLLAND,R.; OTOBONI FILHO,J.A.; SOUZA,V, NERY,M.J.; BERNABÉ,P.F.E.; DEZAN JUNIOR,E. Mineral trioxide aggregate repair of lateral root perforations. J. Endod., v.27, p.281-4, 2001.

40. HOLT,S.C.; EBERSOLE,F.; FELTON,F.; BRUNSVOLD,M.; KORNMAN,K.S. Implantation of Bacteroides gingivalis in nonhuman primates initiates progression of periodontitis. Science, v.239, p.55-7, Jan. 1988.

41. HOLT,J.G.; KRIEG,N.R.; SNEATH,P.H.A.; TALEY,J.T.; WILLIAMS,S.T. Bergey's manual of determinative bacteriology. 9. ed. Baltimore, Williams \& Wilkins, 1994.

42. HUME,W.R. Effect of eugenol on constrictor response in blood vessels of the rabbit ear. J. Dent. Res., v.62, n.9, p.1013-5, 1983.

43. HUME,W.R. The pharmacologic and toxicological properties of zinc oxide-eugenol. J. Am. Dent. Assoc., v.113, n.5, p.789-91, 1986. 
44. KITADA,K.; INOUE,M.; KITANO,M. Experimental endocarditis induction and platelet aggregation by Streptococcus anginosus, Streptococcus constellatus and Streptococcus intermedius. FEMS Immunol. Med. Microbiol., v.11, n.1, p.25-32, Sept. 1997.

45. LEE,J.G.; KIM,K.S. A microbiologic study on anaerobic bacteremia after dental extraction. Taehan Chikkwa Uisa Hypphc Chi., v.28, n.3, p.299-301, Mar. 1990. /Abstract/

46. MANSON,W.L.; COENEN,J.M.F.H.; KLASEN,H.J.; HORWITZ, E.H. Intestinal bacterial translocation in experimentally burned mice with wounds colonized by Pseudomonas aeruginosa. Trauma, v.33, n.5, p.654-8, Nov. 1992.

47. MARKOWITZ,K; MOYNIHAN,M.;LIU,M.; KIM,S. Biological properties of eugenol and zinc oxide-eugenol. Oral Surg., v.73, n.6, p.729-37, June 1992.

48. McDONALD,J.B.; HARE,G.C.; WOOD,A.W.S. The bacteriologic status of the pulp chambers in intact teeth found to be nonvital following trauma. Oral Surg., v.10, n.3, p.318-22, Mar. 1957.

49. McGOWAN,D.A.; HARDIE,J.M. Production of arterial endocarditis in prepared rabbits by oral manipulation. Br. Dent. J., v.137, n.4, p.129-31, Aug. 1974.

50. MÖLLER,A.J.R.; FABRICIUS,L.; DAHLÉN,G.; OHMAN,A.E.; HEYDEN,G. Influence on periapical tissues of indigenous oral bacteria and necrotic pulp tissue in monkeys. Scand. J. Dent. Res., v.89, n.6, p.475-84, 1981.

51. NAIR,P.N.R. Light and electron microscopic studies of root canal flora and periapical lesions. J. Endod., v.13, n.1, p.29-39, Jan. 1987.

52. NAIR,P.N.R. Apical periodontitis: a dynamic encounter between root canal infection and host response. Periodontol. 2000, v.13, p.12148, 1997.

53. OKUDA,K.; KATO,T.; NAITO,Y.; ONO,M.; KIKUCHI,Y.; TAKAZOE,F. Susceptibility of Bacteroides gingivalis to bactericidal activity of human serum. J. Dent. Res., v.65, p.1024-7, 1986.

54. OTOBONI FILHO,J.A. Processo de reparo de dentes de cães com lesão periapical após tratamento endodôntico em uma ou duas sessões. Influência do tempo de curativo de demora e do material obturador. Araçatuba, 2000. 341 p. Tese (Livre Docência) - Faculdade de Odontologia de Araçatuba UNIVERSIDADE ESTADUAL PAULISTA. 
55. PANZARINI,S.R. Tratamento de dentes com lesão periapical crônica. Influência de diferentes tipos de curativo de demora e material obturador de canal. Estudo histológico em cães. Araçatuba, 1996. 200 p. Dissertação (Mestrado) - Faculdade de Odontologia de Araçatuba - UNIVERSIDADE ESTADUAL PAULISTA.

56. RIBEIRO,F.C. Distribuição das bactérias nas estruturas mineralizadas de dentes com necrose pulpar e granuloma periapical. Bauru, 1997. 172 p. Dissertação (Mestrado) Faculdade de Odonto logia de Bauru - Universidade de São Paulo.

57. RIBEIRO,F.C.; CONSOLARO,A. Aspectos morfológicos dos biofilmes microbianos na osteomielite crônica supurativa e correlações endodôntica e parendodôntica. Rev. FOB, v.7, n.1/2, p.41-47, jan./jun. 1999.

58. RIBEIRO,F.C.; CONSOLARO,A. Distribuição das bactérias nas estruturas mineralizadas de dentes com necrose pulpar e granuloma periapical. Rev. Dental Press. Bio. Oral, v.1, n.1, p.1730, jan./abr. 2000.

59. ROBINSON,H.G.; BOLING,L.R. The anachoretic effect in pulpitis. I Bacteriologic studies. J. Dent. Assoc., v.28, n.1, p.268-82, Feb. 1941.

60. ROSA NETO,J.J. Estudo em microscopia eletrônica de varredura do ápice radicular e do limite de obturação em dentes portadores de lesão periapical crônica. Araraquara, 1997. 211 p. Dissertação (Mestrado) - Faculdade de Odontologia de Araraquara - UNIVERSIDADE ESTADUAL PAULISTA.

61. SAKAMOTO,H.; NAITO,H.; OHTA,Y.; TANAKNA,R.; MAEDA,N.; SASAKI,J.; NORD,C.E. Isolation of bacteria from cervical lymphonodes in patients with oral cancer. Oral Surg., v.44, p.78993, 1999.

62. SALYERS, A. A., WHITT, D. D. Bacterial pathogenesis: a molecular approach. Washington; American Society for Microbiology, 1994.

63. SELTZER,S. Long-term radiographic and histological observations of endodontically treated teeth. J. Endod., v.25, n.12, p.818-22, Dec. 1999.

64. SILVER,J.G.; MARTIN,L.; McBRIDE,B.C. Recovery and clearance of oral microorganisms following experimental bacteremias in dogs. Arch. Oral Biol., v.20, n.10, p.675-9, Oct 1975. 
65. SILVER,J.G.; MARTIN,A.W.; McBRIDE,B.C. Experimental transient bacteremias in human subjects with varying degrees of plaque accumulation and gingival inflammation. J. Clin Periodontol., v.4, n.2, p.92-9, May 1977.

66. SILVER,J.G.; MARTIN,A.W.; McBRIDE,B.C. Experimental transient bacteremias in human subjects with clinically healthy gingivae. $\mathbf{J}$. Clin. Periodontol., v.6, p.33-6, Feb. 1979.

67. SLOTS,J.; GENCO,R.J. Microbial pathogenicity. Black-pigmented Bacteroides species, Capnocytophaga species, and Actinobacillus actinomycetemcomitans in human periodontal disease: virulence factors in colonization, survival, and tissue destruction. J. Dent. Res., v.63, p.412-421, 1984.

68. SMITH,L.S.; TAPPE,G.D. Experimental pulpitis in rats. J. Dent. Res., v.41, n.1, p.17-22, Jan./Feb. 1962.

69. SOARES,I.J.; HOLLAND,R.; SOARES,I.M.L. Comportamento dos tecidos periapicais após tratamento endodôntico em uma ou duas sessões. Influência do cimento obturador. Rev. Bras. Odontol., v.47, n.2, p.34-41, mar/abr. 1990.

70. SUNDQVIST,G.; JOHANSON,E. Bactericidal effect of pooled human serum on Bacteroides melaninogenicus, Bacteroides asaccharolyticus and Actinobacillus actinomycetemcomitans. Scand J Dent Res., v.90, n.1, p.29-36, 1982.

71. SUNDQVIST,G.; CARLSSON,F.; HERMANN,B.; TÄRNVIK,A. Degradation of human immunoglobulins $G$ and $M$ by blackpigmented Bacteroides. J. Med. Microbiol., v.19, p.85-94, 1985.

72. SUTTER,V.L.; KIRBY,B.; FINEGOLD, S.M In vitro activity of cefoxitin and parenterally administered cephalosporins against anaerobic bacteria. Rev. Infect. Dis., v.1, n.1, p.218-23. Jan./Feb. 1979.

73. TER STEEG,P.F., VAN DER HOEVEN,J.S., DE JONG,M.H., VAN MUNSTER,P.J.J., JANSEN,M.J.H. Enrichment of subgingival microflora on human leading to accumulation of Bacteroides species, Peptostreptococci and fusobacteria. Antoie van Leeu-Wenhoek, v.53, p.261-71, 1987.

74. TZIAFAS,D. Experimental bacterial anachoresis in dog dental pulps capped with calcium hydroxide. J. Endod., v.5, n.12, p.591-5, Dec. 1989.

75. LUZ Centeles, G.; MARtín BAjO, M.; PRIETRO PRIETRO, J. Bases microbiológicas de la enfermedade endodóntica y procesos relacionados. In: LIÉBANA UREÑA, J. Microbiologia oral. Madrid, McGraw-Hill, 1995. Cap.34, p.493-510. 
76. WANG,X.; ANDERSSON,R.; SOLTESZ,V.; BENGMARK,S. Bacterial translocation after major hepatectomy in patients and rats. Arch. Surg., v.127, n.9, p.1101-6, Sept. 1992.

77. WIJNBERGEN,M.; VAN MULLEN,P.J. Effect of histological decalcifying agents on number and stainability of Gram-positive bacteria. J. Dent. Res., v.66, n.5, p.1029-31, May 1987.

78. WIJNBERGEN,M.; VAN MULLEN,P.J. The cumulative effect of disinfection storage, histological fixation and demineralization on number and staining ability of Gram-positive bacteria. Int. Endod. J., v.24, n.5, p.243-8, Sept. 1991.

79. YAO,L.; BERMAN,J.W.; FACTOR,S.M.; LOWY,F.D. Correlation of histopathologic and bacteriologic changes with cytokine expression in an experimental murine model of bacteremic Staphylococcus aureus infection. Infect. Immun., v.65, n.9, p.3889-95, Sept. 1997.

80. ZERLOTTI, E.; HOLLAND, R. Reatividade dos grupamentos 1,2 glicol em polpas dentais inflamadas. Ciência e Cultura, v.16, p.214-215, 1964. 
ABSTRACT 


\title{
EXPERIMENTAL INDUCED ANACHORESIS IN DENTAL PERIAPICAL REGION OF TEETH AFTER ROOT CANAL FILLING. STUDY IN ENDEMIC REGION FOR LEISHMANIOSIS.
}

\begin{abstract}
Anachoresis is that phenomenon by which blood-borne bacteria, dyes, pigments, metallic substances, foreign proteins and other materials are attracted to, and fixed in, circumscribed areas of inflammation. This study evaluated the occurrence of anachoresis in the periapical region. 104 roots from four dogs where endodontically treated and root canals filled with zincoxide-eugenol cement. 50\% where filled until the CDC limit and the others overfilled. 120 days after root canal treatment, a experimental bacteremia was induced by means of intravenous inoculation of a Streptococcus pyogenes culture containing $5.10^{6} \mathrm{CFU} / \mathrm{ml}$. Inoculated bacteria presented several antimicrobial resistance markers. The euthanasia of dogs was conducted 48 hours and 30 days after the bacteremia. Microbial processing of periapical tissues evidenced the presence of inoculated microorganisms at 48 hours specimens but not at 30 days samples. Microscopic analysis had evidenced similarity between bacterias of the tissues and the inoculated strain in $46,88 \%$ of the specimens after 48 hours and other microorganisms in $28,12 \%$ after 30 days. Some of these cocci have shown morphological similarities to the inoculated bacterias. They were localized in the cementary canal, apical delta, lateral and apical periodontium in both periods of time. Leishmania sp. was also detected in two dogs. Endodontically treated periapices seemed to be propitious for anachoresis and it was not any relation between the phenomena and root canal filling level. Microorganisms might persist in periapical region and/or collaborate to this tissues colonization by other more sensitive species. The experimental pattern seemed to be adequate for the a nachoresis study.
\end{abstract}

